\title{
Late glacial and post-glacial deposits of the Navamuño peatbog (Iberian Central
}

System): Chronology and paleoenvironmental implications.

Valenti Turua ${ }^{\star}$, Rosa M. Carrasco ${ }^{b}$, Javier Pedrazac ${ }^{c}$, Xavier Ros $^{a}$, Blanca Ruiz-Zapata ${ }^{d}$, Joan Manuel Soriano-López ${ }^{\mathrm{e}}$, Elena Mur-Cacuho ${ }^{\mathrm{e}}$, Albert Pélachs-Mañosa ${ }^{\mathrm{e}}$, Alfonso Muñoz-Martínn ${ }^{c, f}$, Jesús Sánchez ${ }^{\mathrm{b}}$, Anna Echeverria Morenoa

$a^{\star}$ Fundació Marcel Chevallier, Edifici Socio-Cultural de La LLacuna, AD500 Andorra la Vella, Principality of Andorra.

b Dpt. of Geological and Mining Engineering, Univ. of Castilla-La Mancha, Avda. Carlos III, s/n, 45071 Toledo, Spain.

c Dpt. of Geodynamic, Complutense University, C/ José Antonio Novais, 12, 28040 Madrid, Spain.

d Dpt. of Geology, Alcalá University, Ctra. A-Il km 33,600, 28871 Alcalá de Henares, Madrid.

e Dpt. de Geografia, Grup de Recerca en Àrees de Muntanya i Paisatge (GRAMP), Universitat Autònoma de Barcelona (UAB). Edifici B. Fac. Filosofia i Lletres, 08193 Bellaterra (Cerdanyola del Vallés), Barcelona.

f Instituto de Geociencias - IGEO (UCM, CSIC), C/ José Antonio Novais, 12, 28040 Madrid, Spain.

${ }^{*}$ Corresponding author. Tel.: + 376321815

E-mail address igeofundacio@andorra.ad (Valenti Turu)

Keywords: Paleoclimate, sedimentary charcoals, deglaciation, geochemistry, LOI, Iberian Central System. 


\section{Abstract}

The Navamuño peatbog (Sierra de Béjar, western Spain) is a $\sim 14$ ha pseudoendorheic depression with boundaries defined by a lateral moraine of the Cuerpo de Hombre paleoglacier and fault-line scarps on granite bedrock. The stratigraphy of the Navamuño peatbog system is characterized here using borehole data to a depth of 20 m. An integrated interpretation from direct-push coring, dynamic probing boreholes and handheld auger drillings advances our knowledge of the Navamuño polygenetic infill. Correlating this data with those obtained in other studies of the chronology and evolutionary sequence of the Cuerpo de Hombre paleoglacier has enabled us to establish the sequence of the hydrological system in the Navamuño depression. During the Late Pleistocene (MIS2), the depression was dammed by the Cuerpo de Hombre glacier and fed by its lateral meltwaters, and was filled with glaciolacustrine deposits. The onset of the Holocene in Navamuño is linked to a flat, fluviotorrential plain with episodes of local shallow pond/peat bog sedimentation. This evolutionary sequence is congruent with the age model obtained from available radiocarbon dating, obtaining 19 ages from $\sim 800$ cal yr BP (at depth $1.11 \mathrm{~m}$ ) to $\sim 16800$ cal yr BP (at depth 15.90-16.0 m). Finally, the sedimentary record enabled interpretation of the environmental changes occurring in this zone during the late glacial (from the Older Dryas to the Younger Dryas) and postglacial (Holocene) stages, placing them within the paleoclimatic context of the Iberian Peninsula and Mediterranean regions.

\section{Introduction}

The Mediterranean region is an important corridor crossing the low mid-latitudes to the easternmost Mediterranean region, with current penetration of North Atlantic atmospheric depressions. It played a major role in ongoing climate change during Pleistocene cold stages (Hughes and Woodward, 2008). The atmospheric framework of the last glacial cycle in this region may refer to a polar front positioned off Iberia, in 
the North Atlantic Ocean (Ruddiman and Mclntyre 1981; Florineth and Schlüchter, 2000; Roucoux et al., 2005) and a westerly atmospheric circulation between North Africa and Europe (Hughes and Woodward, 2017).

Railsback et al. (2011) described the N-S climatic evolution in the Iberian Peninsula during the interglacials and the Holocene. However, in the last glacial cycle oceanic and atmospheric polar fronts were both further south than in the Holocene (Naughton et al., 2009), and thus produced an intense $\mathrm{N}-\mathrm{S}$ contrast in the Iberian Peninsula.

Latitudinal climatic stratification, as was apparently present during the Holocene (Railsback et al., 2011), would explain how and why important chronological differences exist between equivalent glacial stages (e.g. between local MIEs) in various mountain massifs in the Iberian Peninsula (García-Ruiz et al., 2003, 2010; Hughes and Woodward, 2008, 2017). However, to explain these chronological differences in a single mountain massif is still a problem, even between closer paleoglaciers. E.g., in the Iberian Central System (ICS) the MIEs of some paleoglaciers occur during MIS2, clearly coinciding with the LGM or slightly earlier (Palacios et al., 2011, 2012a, 2012b; Carrasco et al., 2015a). However, in other sites from the same area the MIE is much earlier and either corresponds to MIS2 but precedes the LGM by several thousand years (Domínguez-Villar et al., 2013), or occurs during MIS3 (Vieira et al., 2001; Bullón, 2016). These latter chronologies of some ICS paleoglaciers, correlate better with those most frequent obtained in northern and north-east mountain massifs in the Iberian Peninsula for the local MIEs (García-Ruiz et al., 2003; Moreno et al., 2010; RodríguezRodríguez et al., 2015; Serrano et al., 2012, 2017; Delmas et al., 2015). However, the glacial sequence proposed in these other mountains of Iberia, where pre-MIS3 and even pre-Würm phases are detected (Calvet, 2004; Vidal-Romaní and FernándezMosquera, 2006; Lewis et al., 2009; Jiménez-Sánchez et al., 2013; RodríguezRodríguez et al., 2015; Serrano et al., 2017; Turu et al, 2017), completely unlike from the glacial sequence proposed for the ICS (Pedraza et al., 2013; Carrasco et al., 
2015a). To provide a regional and supra-regional scale paleoclimate and chronostratigraphy correlations, our research into ICS envisage further exploration of two study approaches: (1) the sedimentary record looking for specific glacial stages, and the paleoenvironmental record using different proxies (LOI, charcoals, magnetic susceptibility, sedimentary facies, type of sedimentary discontinuities, ...); (2) AMS ${ }^{14} \mathrm{C}$ chronological data to complement the original data obtained from surface mapping and dating, mainly based on Terrestrial Cosmogenic Nuclide (TCN). Both approaches aim to clarify such glacial evolution differences in the ICS, especially regarding the Mediterranean climate variability.

\section{Main scope}

Dating lacustrine records in a similar geomorphological context like Navamuño can provide useful paleoenvironmental information (i.e. González-Sampériz et al., 2006; Jalut et al., 2010), and can be used to solve TNC uncertainties, or complement glacial correlations at a local, regional, or even global scale. Similar experience has proven very useful for establishing some glacial stages (Carrasco et al., 2015a) with the Cueva del Águila (Domínguez-Villar et al., 2013), where a climate record compiled from speleothems is currently available. Well-contrasted paleoenvironmental data is available in central and western Iberia providing a general base reference for glacial records (see e.g.: Jalut et al., 1992, 2010; Harrison and Digerfeldt, 1993; Naughton et al., 2009; Moreno et al., 2012; Arambarri et al., 2014; González-Sampériz et al., 2017).

Unfortunately, any useful lacustrine records from the ICS are available. Those that are related with glacial geomorphology are limited in thickness and only provide data on postglacial stages (see e.g.: Ruiz-Zapata and Acaso-Deltell, 1981, 1984; RuizZapata et al., 1996, 2011; Franco-Múgica, 1998; Rubiales et al., 2007; López-Sáez et al., 2014, 2016; Abel-Schaad et al., 2014; Sánchez-López et al, 2016; Génova et al., 2016). For that reason, any available information about ICS glacial features is mainly 
based in geomorphological mapping, backed by TCN dating. However, paleopalynological studies of hydro-peat sediments in the Navamuño starts quite soon (Atienza, 1993) reaching $3 \mathrm{~m}$ depth and up to $\sim 6$ ka BP. Far after Ruiz-Zapata et al. (2011) improved until $4.5 \mathrm{~m}$ depth but less further in time (up to $\sim 5.1 \mathrm{ka}$ BP). All these results are similar to those obtained in some places from the ICS, although none of the boreholes in this depression reached the bedrock. Taking into account this background, systematic studies were undertaken using geological and geophysical surveys to investigate the geometry and structure of Navamuño depression, its relationship with the Cuerpo de Hombre paleoglacier and magnitude of the infill by Carrasco et al. (2008). These studies reveal a minimum sedimentary infill over $40 \mathrm{~m}$ deep, and therefore appropriate for paleoenvironmental and chronological studies of the last glacial cycle (Carrasco et al., 2015b). Only a systematic research that applies multiple subsoil investigation procedures (geophysical and mechanical test probes supported by ${ }^{14} \mathrm{C}$ dating) can provide an integrated sedimentological, chronological and environmental study of the Navamuño deposits. This study also enlarges the knowledge about relationships between the Navamuño depression and the former Cuerpo de Hombre glacier.

\section{Study area}

The Navamuño Depression (ND) is a small depression ( $14 \mathrm{Ha})$ on the western slopes of Sierra de Béjar (W Spain), associated with the large fault-corridor type Hervas-Sorihuela depression and the Cuerpo de Hombre paleoglacier (Carrasco et al., 2015a, 2015b). The ND presents characteristic traits of navas in the ICS, i.e.: flat, treeless, sometimes marshy ground (or peatbog) and generally situated between mountains (Fig. 1). The ND is limited to the east by the left lateral moraine of the Cuerpo de Hombre paleoglacier, responsible for the obstruction and consequent filling of the depression in the upper Pleistocene. The other limits are related to fault-line 
scarps on monzogranites and granodiorites of one of the great granitic batholiths of the Iberian Massif (Villaseca et al., 1999, Villaseca, 2003), locally transformed by weathering processes (grus, regolith and spheroidal weathering formations). The current geomorphological processes in this area are characterised by an attenuated periglacial environment characteristic of a Mediterranean mountain climate with very slight Atlantic influence (AEMET/IM, 2011).

The bottom of the depression is an alluvial plain drained by two channel systems, which present networked patterns, depending on the zone (Fig. 2). Except for some locally flooded strips, the channels are well defined, Except for some locally flooded strips, with thalwegs entrenched in the alluvial plain between $0.5 \mathrm{~m}$ (southern zone) and $1.5 \mathrm{~m}$ (northern zone). The drainage network in the depression emerges from the southern border with two simple, moderately confined channels, which on reaching the plain expand into a system of multiple channels forming two alluvial fans. This process interconnects both networks in the centre of the depression and finally they converge at the northern edge to form a single outflow channel (Arroyo de Navamuño). This torrent is fed by superficial waters but also by groundwater interception along the whole path through the Cuerpo de Hombre river confluence. The confined channels in the south of the depression are located on both sides of a terracelike platform adjoining the Cuerpo de Hombre paleoglacier lateral moraine. This morphological unit corresponds to an alluvial deposit system originated in the marginal meltwaters of the ancient glacier, identified as a marginal or kame terrace (Carrasco et al., 2015a). Thus, ND presents a drainage system with two well-defined supply sources: the western slope drainage basin (Arroyo del Puerto de Navamuño) and the eastern slope drainage basin forming the left lateral moraine of the Cuerpo de Hombre paleoglacier (Arroyo del Refugio). These two drainage systems have been well differentiated quite early in the former relief, and therefore have been responsible for the infill path of the depression. 


\subsection{Dynamic Probing Super Heavy (DPSH)}

Previously to coring, we proceeded to investigate the thickness of the sedimentary layers using DPSH test. The probe was carried out using a conepenetrometer reaching $22.8 \mathrm{~m}$ depth. The testing point was in the ND distal zone, $40^{\circ}$ $19^{\prime} 16.306 " \mathrm{~N}, 5^{\circ} 46^{\prime} 42.229 " \mathrm{~W}$. Dynamic probing drives a cylindrical sacrificial or fixed cone into the ground using a high frequency percussive $63.5 \mathrm{~kg}$ hammer, with a fixed drop height of $750 \mathrm{~cm}$. The cone is $90^{\circ}$ shaped and attached to a $1 \mathrm{~m}$ section steel rod with two-inch nominal diameter (approximately ø51 mm) and graduated markings set at $20 \mathrm{~cm}$ intervals. In soft sediments, some static penetration induced from the weight of the steel rods have been taken into account. This effect increases with the borehole depth, as each steel rod weighs $6 \mathrm{~kg}$. Below the water table, corrections are required to account for static water pressure. In less permeable soils, percussion frequency must be slower. Otherwise, the results may be erroneous since significant energy can be transmitted to the interstitial water, thus increasing the blows needed to penetrate the ground. If the blows are excessive (> 100 blows per $20 \mathrm{~cm}$ penetration) the ground resistance may be excessive for coring using this perforation system and thus the test is stopped.

Before presenting the results, the Dynamic Penetration Resistance (DPR) is calculated using the 'Dutch formula' $(\mathrm{Qd})$. This equation uses the penetration interval (e $=20 \mathrm{~cm})$ for a given penetration area $\left(\pi \cdot r^{\wedge} 3\right)$, hammer weight $(M)$, drop height $(H)$ and weight of the steel rod $(P)$ at any depth $(P \cdot h)$, subtracting the static interstitial water pressure exerted by the phreatic surface (Sanglerat, 1967):

$$
Q d=M^{2} \cdot H \cdot[e \cdot A \cdot(P \cdot h+M)]^{-1}
$$




\subsection{Core sampling}

A Russian type "Handheld power earth auger" (HPEA) was used in borehole S0 and a "Mechanized driller" (MED) was used for boreholes S1 and S2 (Table 1). However, in Navamuño these methods proved to be limited for obtaining core samples at depths of over $6 \mathrm{~m}$. To reach a greater depth in the borehole S3 a hydraulic device was used which actions a piston and in turn a percussion hammer. The direct percussive force exerted allowed collection of samples (DP) $\varnothing 43 \mathrm{~mm}$ and $1.5 \mathrm{~m}$ long in a $\varnothing 63 \mathrm{~mm}$ steel core drill until $6 \mathrm{~m}$ depth. Soil liquefaction at $6 \mathrm{~m}$ depth made it impossible to sample using the simple piston corer inside the casing. The casing was therefore used directly for cores between 6 and $10.5 \mathrm{~m}$ depth, helped with a $\varnothing 44$ pressuremeter cell. The pressuremeter has a flexible, inflatable membrane cell, which exerts pressure of up to $2 \mathrm{MPa}$ on the walls during the sample extraction process. The pressuremeter cell has two functions: to obstruct the casing entrance, acting as an extraction spoon and to isolate the sample from the suction exerted by the terrain in the extraction operation. This is achieved by inflating the pressuremeter cell behind the sample during the extraction process.

Below $10.5 \mathrm{~m}$ depth, this procedure was no more effective. At this depth, when the tube was raised-up in order to extract the sample vacuum is self-created inside the core. At such depth, groundwater could be degasified following the Boyle's law, getting decompressed the dissolved gases. This process inhibits the induced sealing that may be produced by the pressuremeter cell and thus loosing the sample. To solve the suctioning problem that drives the sample until the bottom of the borehole, a twodirectional port was installed at the entrance to the casing. During the extraction procedure, the suction phenomenon is 'shortcircuited'. The soil sample into the tube induces the closure of the two-way port entrance when vacuum is created at the bottom of the borehole. Then the sample remains in the extractor and once recovered, 
218 the sample is extracted from the casing using a hydraulic piston. Then, as it emerges

219 from the casing it is enclosed in a PVC sleeve split in two to allow later closure and sealing.

As the cores were extracted, a first in situ description was made looking at the sedimentary characteristics (coarsening or fining-upward) and thickness (thinning or thickening-upward). In order to locate sub-aerial exposures like weathered layers and paleosols, unconformities and therefore hiatuses or erosive surfaces, systematic magnetic susceptibility measurements were done directly in the field to identify what may not be so evident in these kind of visual identifications. So surface contact type and possible unconformities can be easily identified and a precise sedimentary characterization sequence is produced in-situ. mineralogy and geochemistry of the environments where the materials were formed. This information on their origin may provide more data on the environmental conditions in which the minerals were incorporated into the sediments (flooding, exposure to weathering, hiatuses, erosion surfaces, etc.). Coarse grained sediments generally present greater magnetic susceptibility than fine grained sediments. This empirical

242 observation is based on the fact that the dense ferromagnetic minerals associate with

243 the coarsest materials (channel lag) during transport and deposition processes (Brown and Pasternack, 2004). 


\subsection{Dating method}

Seventeen core samples were analysed corresponding to boreholes S0, S1, S2 and S3 (Table 2). In addition, the following samples were included for analysis: Poz40322 (S0, Ruiz-Zapata et al., 2011) and Poz-49562 (S1, Carrasco et al., 2015b). When collecting samples for ${ }^{14} \mathrm{C}$ dating, priority was given to fine grained peat sediments, as these materials tend to have a higher organic matter content in situ. Following this procedure, in this selection the materials corresponding to proximal facies (fluvio-glacial) were discarded; the high meltwater energy and oxygenation may reduce the quantity of organic material in the sediment by physical and/or chemical means (disaggregation, dilution, oxidation). The high porosity and permeability of the fluvioglacial facies may also induce carbon migration through groundwater filtration, a well-known hydrogeological phenomenon (El-Kadi et al., 2011). Possible biological contaminants (e.g. fungi) were avoided by drying samples immediately on collection. Once dry, the samples were isolated with aluminium foil, placed in a plastic bag and stored at $4^{\circ} \mathrm{C}$ in a dry, dark place until sent to the laboratory. On arrival at the laboratory, the organic matter was extracted using ABA protocol, consisting of an acidbase-acid $(\mathrm{HCl}-\mathrm{NaOH}-\mathrm{HCl})$ wash to eliminate carbonates and possible humic acids. The resulting fraction was dried and prepared for dating. voluminous organic fractions using the Beta Analytic Inc. (Florida, US.) mass spectrometer. CALIB 7.0.4 and INTCAL13 curves (Reimer et al., 2013) were used to calibrate the data. AMS $\left({ }^{14} \mathrm{C}\right.$ y $\left.{ }^{10} \mathrm{Be}\right)$ data from previous research by the authors of this paper (Ruiz-Zapata et al., 2011; Carrasco et al., 2015a, 2015b) were also used to obtain the chronological sequence. 


\subsection{Loss on Ignition and sedimentary charcoals}

To determine the organic matter percentage weight the Loss on Ignition test (LOI) was used following the methodology described in Luque (2003), based in turn on the standard procedure Dean (1974). The weighed samples were dried at $60{ }^{\circ} \mathrm{C}$ for 48h. The samples were then combusted at $550{ }^{\circ} \mathrm{C}$ for $4 \mathrm{~h}$, omitting the second combustion proposed in the methodology.

The sediment microcharcoal count was performed using a physico-chemical process following the Carcaillet protocol (Carcaillet et al., 2001, 2007). To minimize the effects of the different sample densities, the choice was made to work with weight ( 1gr) rather than volume. The samples were weighed and then heated at $70{ }^{\circ} \mathrm{C}$ for 90 minutes, adding two tablets of a deflocculant solution of potassium hydroxide $(\mathrm{KOH})$, $20 \mathrm{ml}$ of hypochlorite solution $(\mathrm{NaClH})(15 \%)$ to each sample to eliminate organic matter and respectively bleach the samples (Finsinger et al., 2014). A $150 \mu \mathrm{m}$ mesh was used for filtration and subsequent count under a binocular microscope (40x magnification), calculating the area using an ocular micrometer with a graticule of $10 \times 10$ squares each with area $0.0625 \mathrm{~mm}^{2}$ (Carcaillet et al., 2001).

\section{Results and interpretation}

The data and their interpretation are described in this section. Figure 3 has been elaborated that syntheses correlations between sedimentary layers and some of their properties, obviously theses that had been analyzed in this work.

\subsection{Dynamic Probing Super Heavy sounding, DPSH}

A DPSH borehole has been done down to $\approx 20 \mathrm{~m}$ depth. Three decreasing Qd trend segments were obtained (Fig. $3 \mathrm{H})$. The first segment is at 0.0-5.8 $\mathrm{m}$ depth, slight increases in Qd resistance were observed in the first $5 \mathrm{~m}$, correlated with fine-grain sand layers. From 5.8-7.2 m depth an increase in Qd was observed, interpreted as 
increasing grain size with depth. In segment 7.2-13.1 $\mathrm{m}$ depth, a steady decrease in

Qd penetration resistance was observed, reflecting incremented interstitial pressure by the groundwater at that depth, promoting a loss of consistency in the sandy layers. The groundwater aquifer may be pressurised here, with a greatest pressure exerted at the bottom of the sandy layer. Down to $16 \mathrm{~m}$ depth a $\mathrm{Qd}$ shifting trend can be observed in Fig. $3 \mathrm{H}$, that may be related with the increase of thin organic silty clay in between sands. Despite a minor Qd decrease down to almost $16 \mathrm{~m}$ depth, massive grey clays were detected in the obtained core samples, and such materials may be present down to depths of $18-19 \mathrm{~m}$.

Finally, a rapid DPR increase was observed to a depth of $20 \mathrm{~m}$, which may be related to greater lithological discontinuity detected in earlier surveys (Carrasco et al., 2015b). Below this discontinuity there is a further decrease in Qd, although it is difficult to interpret the nature of the involved materials at this depth.

\subsection{Borehole data}

\subsubsection{Auger S0}

The initial manual perforation was performed in the central part of the peatbog (see Table 1) with sequence layers obtained as follows: (1) $0.30-1.00 \mathrm{~m}$, spongy and massive peat; (2) $1.00-1.80 \mathrm{~m}$, black mudstones gradually becoming grey at greater depths; (3) $1.80-2.35 \mathrm{~m}$, dark laminated organic mudstones with a grey silty layer between $2.00-2.10 \mathrm{~m}$ and wood fragment found at $2.25-2.35 \mathrm{~m}$; (4) $2.35-3.60 \mathrm{~m}$, mudstone rich in dark organic matter with sandy layer intercalations between 2.35 2.40 m depth; (5) 3.60 - 4.20 m, mudstone sediment, now brown; and (6) $4.20-4.75$ $\mathrm{m}$, grain-size increasing to gravel preventing further perforation. 


\subsubsection{Percussion Drilling S1}

A sampling equipment that uses a percussion petrol engine was used in the central part of the peatbog. From top to bottom the obtained samples were: (1) 0.00 $2.23 \mathrm{~m}$, clay and silt sediments (mudstones); (2) $2.23-2.81 \mathrm{~m}, \varnothing 2 \mathrm{~cm}$ gravels and ø2$ø 3 \mathrm{~mm}$ coarse sands; (3) $2.81-3.00 \mathrm{~m}$, another mudstone layer; (4) $3.00-3.50 \mathrm{~m}$, coarsening-upward sequence of fine sand to mudstone; 5) $3.50-4.85 \mathrm{~m}$, coarseningupward layer of sand and mudstone, especially rich in organic matter between 3.75 and $3.78 \mathrm{~m}$; (6) 4.85 - $5.00 \mathrm{~m}$, mudstone; and (7) $5.00-5.50 \mathrm{~m}$, sand and gravel. Although the perforation reached a depth of $8.00 \mathrm{~m}$, the core sample extracted presented loss of consistency, and was therefore not taken into account and the Poz49564 dating was discarded. Due to the thickness of the gravel layer, perforation was not feasible at greater depths.

\subsubsection{Percussion Drilling S2}

Performed in the southern side of the peatbog. From top to bottom the sequence obtained was: (1) $0.00-2.71 \mathrm{~m}$, mudstone layer containing thin intercalated gravel layers between 0.67-0.72 $\mathrm{m}$ depth, 1.14-1.17 $\mathrm{m}$ depth and 1.50-1.56 $\mathrm{m}$ depth; (2) $2.71-3.92 \mathrm{~m}$, a sand and gravel layer was reached with high clay content, and a silt layer between 3.86 and $3.92 \mathrm{~m}$ depth. Although perforation continued to $5 \mathrm{~m}$ depth, as in S1 progress became very difficult, and as it was impossible to collect unaltered cores, it was decided not to continue the perforation.

\subsubsection{Direct Push Drilling, S3}

The third borehole was drilled in the distal part of the peatbog, beside S0 and S1 (see Fig. 3B - Fig. 3F). The identified layers, grouped in sequences from top to bottom are the following ones:

SQ-I: 0.00-1.35 m. Thinning-upward sequence formed by layers: (1) silty sands with organic soil remains $(0.00-0.12 \mathrm{~m})$; (2) light umber-coloured silts $(0.12-0.50 \mathrm{~m})(3)$ 
351 a fining-upward strata of silty clays becoming a biotite-rich arkose layer at greater 352 depths $(0.50-0.86 \mathrm{~m})(4)$ a final layer of very fine light umber-coloured silty sand (0.86 $353 \quad 1.35 \mathrm{~m})$.

354 SQ-II: $1.35-5.12 \mathrm{~m}$. Thickening-upward sequence formed by three finingupward layers and a lower coarsening-upward layer. The first three layers are: (1) dark brown peat $(1.35-2.54 \mathrm{~m})$ containing frequent roots and plant remains $(2.16-2.35 \mathrm{~m})$; (2) dark umber-coloured silt and sand (2.54-2.92); and (3) light umber-coloured silt with gravel $(2.92-3.50 \mathrm{~m})$. The next segment $(3.50-4.42 \mathrm{~m})$ consists of layers: $(4)$ sand (3.50-3.92 m) presenting a quartz gravel layer at $3.78 \mathrm{~m}$ depth; (5) black silts (3.92-

$4.14 \mathrm{~m}) ; \quad$ (6) fine grain sand with some black silts $(4.14-4.35 \mathrm{~m}) ;(7)$ coarse sands (4.35-4.42 m); (8) very fine sands (4.42-4.56 m) and (9) dark brown sands (4.56-4.65). The coarsening-upward texture at the base $(4.65-5.12)$ corresponds to layer $(10)$ formed by highly organic dark brown sediment with plant remains located at 4.87-5.06 m depth.

SQ-III: $5.12-6.05 \mathrm{~m}$. Thickening, fining-upward sequence, formed by sands and gravels alternating with layers of coarse sands, where the following levels can be differentiated: (1) coarse grain sands $(5.12-5.25 \mathrm{~m})$; (2) dark brown fine grain silty sands with gravel intercalations $(5.25-5.31 \mathrm{~m})$; $(3)$ medium to very coarse sands (5.31-5.43 m); (4) very coarse to medium sands (5.43-5.56 m); (5) gravels changing to coarsening-upward segments. The upper segment presents layers: (1) angular gravels mixed with rounded gravels up to $ø 2 \mathrm{~cm}$, with coarse sands at the base $(6.05-6.40 \mathrm{~m})$; (2) gravels with pebbles of up to $ø 2 \mathrm{~cm}$, changing at the top to medium grain sands mixed with brown silt $(6.40-7.21 \mathrm{~m})$. The lower segment is formed by layers: (3) gravels with $\varnothing 1 \mathrm{~cm}$ pebbles which change towards the base to very coarse sands $(7.21-7.53$ $\mathrm{m})$; (4) umber-coloured silty sands (7.53-7.58 $\mathrm{m}$ ) and (5) dark brown silt (7.58-8.17 m). 

upward type segments. The upper fining-upward type segment presents the following layers: (1) medium sands changing towards the base to coarse sands (8.17-9.10 m; (2) alternating medium and coarse sands $(9.10-10.70 \mathrm{~m})$. The lower segment presents layers: (3) very coarse sands (10.70-11.96 m) and (4) coarsening-upward texture formed by alternating coarse silts and sands with lower mudstone content (11.96-13.03 $\mathrm{m})$.

SQ-VI: $13.03-14.00 \mathrm{~m}$. Sequence with predominantly fining-upward texture presenting the following layers: (1) medium sands mixed with dark brown silt (13.03$13.61 \mathrm{~m})$; (2) alternating textures of medium and fine sands mixed with umber-coloured silt $(13.61-13.90 \mathrm{~m})$. In this layer remains were observed of charred materials and charcoal, which act as detrital grains in a thin brown silt-sand layer located at $13.9 \mathrm{~m}$.; (3) medium sand mixed with brown silt in which macro-charcoal and charred materials were identified (13.90-14.00 m).

SQ-VII: 14.00-15.43 m. Sequence formed by a silt-clay layer, homogeneous in composition but presenting colour variations: (1) dark green (14.00-14.19 m), (2) dark brown (14.19-14.95 m); (3) dark green (14.95-15.19 m); and (4) dark green/light umber (15.19-15.43 m).

SQ-VIII: 15.43-16 $\mathrm{m}$. Sequence presenting sediments similar to the above with the following levels: (1) upper layer formed by dark grey-brown clay silts (15.43-15.62 m) (2) similar layer but dark greenish-brown (15.62-15.76 m). Below these are two clay layers: (3) greyish tones (15.76-15.81 m) and (4) greenish-grey tones (15.81-15.90 m). At the base, layer (5) bluish silts (15.90-16.00 m). Probably the layers continue thus below $16.00 \mathrm{~m}$ down to $19.00 \mathrm{~m}$, depth at which increased penetration resistance was recorded (see Fig. 3H). The unusual nature of these fine grain sediments found at the bottom of the borehole led to a specific study to characterize them, (see annex to this publication). 
407 (low plasticity silt) following USCS (Unified Soil Classification System) with 7\% organic 408 matter and some carbonate, as it presented a slight reaction with hydrochloric acid. 409 However, the clay content is high (25\%) and the sample is composed mainly of quartz and feldspar (55\%) and to a lesser extent chlorite (20\%) and kaolinite (25\%). The greenish colour of the sample is certainly due to the chlorite content and the bluish colour to non-oxidised iron. Analysing the particular chemical composition of the sample, it was observed that the $\mathrm{K}_{2} \mathrm{O} / \mathrm{CaO}$ ratio is lower than 4.3 , locating it in the geochemical field of granites and granodiorites source areas (Muhs et al., 2017), as in the case of the ND. Thus, $75 \%$ of the clay fraction (quartz, feldspar and chorite) can be attributed to erosion of the normal calc-alkaline series plutonic rocks, and the kaolinite to temperate climate hydrolysis of the surrounding peraluminous rocks (Chamley, 1989). Bedrock weathering by favourable climatic conditions promotes aluminium leaching and its content has been used as a palaeoenvironmental proxy for titanium content in a variety of settings (Breuer et al., 2013). The Al/Ti index in ND presents a very high value (27.7), showing that the detrital contribution to the depression was minimal (Höbig et al., 2012), and in all cases produced by suspension in an aqueous medium.

\subsection{Field Magnetic susceptibility data (MS)}

The magnetic susceptibility (MS) measurements were plotted and the most important data were labelled (see Fig. 3G), resulting in a mean value close to $10^{-4} \mathrm{SI}$. Half of the labelled data have MS higher than the mean value. Some of these values are related to fine grain organic sediments, in which plant macroremains were identified (labels 1, 3, 15 and 17) of edaphic origin with an iron-rich illuvial Bt horizon. Label 17 becomes just after a maximum flooding surface, in a Forced High Stand. Many grains of edaphic origin have extremely fine magnetic particles (Sartori et al., 1999) which 
$m$ depth (label 15$)$ is of particular interest, where the magnetic susceptibility $\left(1.89 \cdot 10^{-4}\right.$ $\mathrm{SI}$ ) is almost twice as high as the mean value obtained in the other sub-aerial surfaces, here reaching a Forced High Stand posterior to a maximum flooding surface (mfs), Fig. 31.

In other cases, the organic matter present in the fine grain sediments may have given rise to more reductive conditions and to a greater loss of magnetic detrital particles associated with it. This is the interpretation of data obtained from layers at 3.1 and $4.81 \mathrm{~m}$ depth (labels 5 and 7 ). During diagenesis, the magnetite may have dissolved on contact with reductive or acid matrix fluids (Singer et al., 1996) and iron leaching through porous media resulted in the loss or reduction of the MS signal. Here the groundwater flows through permeable flowpaths, such as stratigraphic contacts. This is the case at level $4.81 \mathrm{~m}$ (label 7). Leachates may also find a flowpath out of the system by conduits in the relatively coarse sandy deposits, as in level $3.21 \mathrm{~m}$ (label 5). An edaphic footprint of illuviation is also observed in the A horizon and of accumulation in the Bt horizon. In this context, the resulting low MS at $7.96 \mathrm{~m}$ depth and at $13.16 \mathrm{~m}$ depth (labels 10 and 14) correspond to leached A horizons. Facies changes in the parasequences (Fig. 3D and 3E) allows to identify a transgressive surface at label 10 (Fig. 3I). On the other hand, some of the highest values labelled are linked to coarser sediments (labels 2, 4, 6, 8, 9, 11, 12 and 13). Deviation from this general pattern is observed at level $3.21 \mathrm{~m}$, where low MS values are obtained. This sandy layer is in between the upper and lower layers (label 5), perhaps related to postdepositional diagenesis of magnetic minerals.

Another deviation was observed in label 6 . In this case, the MS shows low values between $15 \mathrm{~m}$ and $14 \mathrm{~m}$ depth. The chemical reduction of the organic matter notably decreases the MS of the whole layer. The base of the layer, at $15 \mathrm{~m}$ depth, a stratigraphic surface boundary (Fig. 3I) may refer to a transgressive sequence until a Forced High Stand starts with the increasing of MS values close to $14 \mathrm{~m}$ depth. 

useful implications can be inferred for subdividing the sedimentary sequence. E.g. the coarsening and thickening-upward stacking between labels 14 and 13 presents positive MS correlation, which occurs again towards label 12 and label 11. Although label 10 displays a low MS value, again direct correlation between MS and grain-size ratio occurs up to label 9. At level $7.95 \mathrm{~m}$, a trend starts to a general decrease in MS and a thinning-upward trend over the previous stacking. Although a thicker layer appears to label 8, a general fining-upward trend increases the lower MS values to label 7 . Thin agree with the assignment of a maximum flooding surface (Fig. 3I) just before label 7 .

\subsection{Age model}

The chronologies of the analysed ND sediments obtained by AMS ${ }^{14} \mathrm{C}$ dating are shown in Table 2. The S3 core log was taken as reference for the age model, with the DPSH log to $18.6 \mathrm{~m}$ depth (see Fig. $3 \mathrm{H}$ ), which marks the start of glaciolacustrine sedimentation. This process must be correlated with the initial obstruction of the ND paleolake, coinciding with the Cuerpo de Hombre paleoglacier MIE (25.0 $\pm 1.3 \mathrm{ka} \mathrm{BP}$; Carrasco et al., 2015a).

The topographical proximity of S0, S1 and S3, meant an age model depending 8.00 m depth (Fig. 4), as explained above in Methodology (4.3). $\mathrm{m}$ depth and $15.5 \mathrm{~m}$ depth. The dates of both samples are within the glacial retreat phases recorded in the Cuerpo de Hombre paleoglacier (Carrasco et al., 2015a), in other ICS areas (Palacios et al., 2012b) and in general in all mountain systems in the 
Iberian Peninsula (Jalut et al., 2010; Rodríguez-Rodríguez et al., 2011, 2015; Gómez-

Ortíz et al., 2012; Jiménez-Sánchez et al., 2013; Palacios et al., 2017; Serrano et al., 2017). In particular, this segment between 16 -15.5 m depth $(\beta-412870,16339-16800$ cal yr BP \& $\beta-410004,13568-13835$ cal yr BP) is synchronous with the onset of climatic events GS-2a (16900 cal yr BP), GI-1e (146942 cal yr BP) and GI-1c (13904 cal yr BP) from Lowe et al. (2008) and Rasmussen et al. (2014). During this period, the ND presents the lowest sedimentation rate of the whole core $(0.17 \mathrm{~mm} / \mathrm{yr}$, Fig. $3 \mathrm{~A})$, coherent with a sedimentary contribution in aqueous suspension with silt and clay deposition on the bottom of the plain. Here warm atmospheric conditions would have been temperate enough to generate abundant kaolinite, which is present in the sample taken at the base of the borehole $(16 \mathrm{~m})$, probably during the Bølling-Allerød interstadials (Fig. 3J).

An arid cold event found by Vegas (2006) in the western Iberian Range (E Spain) at the end of the Allerød (GI-1a), and the end of the GS-1 interval (or Younger Dryas, YD) is represented here by sample $\beta-410003$ (11264-11619 cal yr BP), at 13.3 $m$ depth (Fig. $3 \mathrm{C}$ and $3 \mathrm{~K})$. During this period the sedimentation rate increased $(0.75$ $\mathrm{mm} / \mathrm{yr}$, Fig. 3A). This increment may have been caused by increased erosion on the nearby slopes, as evidence exists of paleoburnings from the macrocharcoals identified 410003) and 10949-11072 cal yr BP ( $\beta$-410001) the rate increases considerably (12.645 mm/yr, Fig. 3A) to the onset of the Holocene, at 11603 cal yr BP (Lowe et al., 2008; Walker et al., 2009). The hydromorphic soils typical of a marshy environment which had predominated during the Younger Dryas (GS-1a), gave way to an alluvial 514 plain environment during the Holocene. From the results of geophysical surveys carried out in the ND (Carrasco et al., 2015b), the depression sedimentary infill was produced 
516 by lateral accretion, on a meander-type pattern (Cserkész-Nagy and Sztanó, 2016).

517 The alluvial plain paleogeography would have presented a flooded zone at the western

518 edge, similar to the current situation, but deeper. In contrast, the eastern part would 519 have emerged to progress as a flood plain, where paleosols can be found, such as that dated at $7.85 \mathrm{~m}$ depth (Fig. 3C).

The sedimentation rate between $7.85 \mathrm{~m}$ depth $(\beta-410001 ; 10949-11072 \mathrm{cal} \mathrm{yr}$ BP) and $7.00 \mathrm{~m}$ depth ( $\beta-410000 ; 10636-10740 \mathrm{cal} \mathrm{yr}$ BP) decreases to $2.69 \mathrm{~mm} / \mathrm{yr}$ (Fig. 3A). This sedimentation rate is similar to La Mata glacial lake (Jalut et al. 2010), in the Montes de León range. Climatic context from this segment includes arid phases in the western Mediterranean around 10900-9700 cal yr BP (Jalut et al., 2000), and decreasing river activity in the western Mediterranean (Magny et al., 2002). This sedimentary rate remains similar $(1.93 \mathrm{~mm} / \mathrm{yr})$ if the Poz-49562 dating (10099-10007 cal-yr BP, Table 2) is included in the age model, corresponding to a sample collected at $5.67 \mathrm{~m}$ depth in borehole S1, $40 \mathrm{~m}$ west of S3.

The pattern of ground resistance to dynamic penetration (see Fig. $3 \mathrm{H}$ ) changes before and after 5.60-5.80 $\mathrm{m}$ depth and the fining-upward grading of the strata is less thick above that depth. Dating at 4.75 m depth ( $\beta-40999 ; 6272-6324$ cal yr BP, Fig. 3C) agrees with dates obtained at the same depth in borehole S1 (see Table 2). With this dating the sedimentation rate decreases again to values of tens of $\mathrm{mm}$ per year $(0.24-0.6 \mathrm{~mm} / \mathrm{yr}$, Fig. 3A). All this indicates that after 10099-10007 cal yr BP (Poz49562) sedimentation conditions changed regarding the previous segment (Fig. 4), producing an increased number of fine-grain layers with plant macro-remains (Fig. 3C). At less depth, the sedimentation rate remains constant $(0.54 \mathrm{~mm} / \mathrm{yr})$ until $472-535$ cal yr BP ( $\beta-409997$, Fig. 3A). Here, peatbog organic clay layers (Fig. 3C) were covered by younger sediments and get inverted (798-870 cal yr BP; $\beta-40997$; Fig. 3A). This shows

541 that the sedimentary accretion no longer continued and scour and fill processes 542 occurred. This led to a reworking of old materials and sedimentation from channel overspill. This rework mixes sediments with organic matter from different age, 
producing age inversion (Rea et al., 1994). This contact is a major stratigraphic surface boundary (Fig. 3l). This process originated in the channel, which currently flows through the $\mathrm{E}$ sector of the depression, very close to the surveyed site.

\subsection{Facies analysis}

In buried soils located at $2.16 \mathrm{~m}$ depth, $4.87 \mathrm{~m}$ depth and $5.0 \mathrm{~m}$ depth, some plant fragments are visible within the sediments (see Fig. 3C) and interpreted as overbank facies coming from flooding. Levels $1.59,4.75,7.0$ and $7.85 \mathrm{~m}$ also contain plant microremains in overbank sediments. This could be explained as 'terrestrial vs. aquatic' interaction of the organic mattter source areas (Wolfe et al., 2002). However, all the available isotopic fractionation data has $\delta^{13} \mathrm{C}$ values lower than $-25 \%$ (see Table 1), corresponding to terrestrial photosynthetic plants C3 type (Walker, 2005).

At the deepest levels, two different final sedimentary members can be differentiated in core S3: (1) wash load (facies code Fm and Fr; see Fig. 3B), predominantly fine and (2) channel bed-load (facies code S and G; see Fig. 3B), predominantly sand or even gravel. Three thickening-upward sequences (see Fig. 3D) are present between 13.10 and $8.10 \mathrm{~m}$ depth, with inverse grading (Fig. 3D) at the bottom and normal grading at the end of each layer. The sedimentation of these three sequences in a relatively short time lapse $(431 \pm 239 \mathrm{yr}$, between $\beta-410003$ and $\beta$ 410001, Fig. 3C) could be considered anomalous, although these values are obtained in river and delta contexts (Miall, 1991). The sedimentation in between implies a rate fifteen or more times higher than the previous sedimentation rate (see Fig. 3A), which perhaps may be interpreted as the presence of a massive flow. This may have been due to channelled grain flows that overran vanished sheet-flows. Inverse grading deposits may be the result of a permanent supply of coarser material from successive deepening floodplain scours (Fig. 3D), such as those produced in crevasse splays (Gebica and Sokolowski, 2001). However, this sedimentary process stops when there 
571 is no material supply and various successive sedimentation stages may occur. Thus,

572 sub-aerial exposure may therefore produce incipient weathering and pedogenesis

573 processes. In this context, iron oxides were observed at $8.23 \mathrm{~m}$ depth and plant 574 microremains at $7.96 \mathrm{~m}$ depth (see Fig. 3C), which may indicate sub-aerial exposure 575 and therefore a sedimentary hiatus.

576 Another inversion of normal alternate grading occurs between levels 8.10 and $5775.13 \mathrm{~m}$ depth (see Fig. 3D), but in a thinning-upward stacking sequence (see Fig. 3E).

578 The non-channelled conditions allow propagation of sheet-flows on the ND flood plain.

579 As the increase in plant macroremains is restricted to the upper part of the sequence, a 580 cyclical decrease in energy during the sedimentary process can be deduced. The decrease in sedimentation velocity also responds to an increased hiatus between overbank deposits. These deposits can be recognised from their inverse grading (Fig. 3D) which originated from flooding of the distributary (Fig. 3F). stacking thickness of the layers (from level 5.13 to level $3.93 \mathrm{~m}$ ), and corresponds to overbank sediments. Over time, the gradual source area denudation during the deposition of each sequence, along with decreasing slope gradients, produced finingupward sequences (Catuneanu, 2006) and thinning stacking. Nevertheless, from level $3.93 \mathrm{~m}$ to $1.48 \mathrm{~m}$ depth, a different stacking pattern occurs, producing thickeningupward stacking (see Fig. 3E) due to a change in fluvial sedimentation style. The absence of inverse grading stacking in an overall fining-upward sequence is compatible with point-bar migration (see Fig. 3F). The current meandering fluvial character probably started at that point in time. The flood plain lag deposits are the result of channel migration and the abandoned channels were filled with fine grain sediment from overbank flooding (see Fig. 3F). This seems to be the case in the level corresponding to the first $1.48 \mathrm{~m}$ depth, located near S3. 
The evolutionary context marked by the indicators and its chronology confirm that the whole Late Glacial sequence identified in Cuerpo de Hombre can be correlated with the traditionally established sequence in northern Europe (Carrasco et al., 2015a): Oldest Dryas-Bølling-Older Dryas-Allerød-Younger Dryas. The minimum ages obtained for the stadials in the Cuerpo de Hombre paleoglacier sequence, are: $17.5 \mathrm{ka}, 13.9 \mathrm{ka}$ and 11.1 ka respectively, obtained from ${ }^{10} \mathrm{Be}-\mathrm{TCN}$ data (Fig. 5). According to the data obtained, the following discussion focus only on the final stage of deglaciation and the Holocene.

\subsection{The Late Glacial period and transition to the Holocene}

The non-laminated grey clays located at a depth of $16.0 \mathrm{~m}$ depth are interpreted as sediments corresponding to an amictic lake with low sedimentation rate $(0.17$ $\mathrm{mm} / \mathrm{yr}$; see Fig. 3A). This is very similar to that of other glacial lakes such as El Portalet in SW Pyrenees (González-Sampériz et al., 2006), which presents a rate of $0.18 \mathrm{~mm} / \mathrm{yr}$ during the same time-period. The geochemical determination (see laboratory appendix, index $\mathrm{Al} / \mathrm{Ti} \approx 30)$ of this core segment between 16 and $15.5 \mathrm{~m}$ depth $(\beta-412870,16339$ 16800 cal yr BP and $\beta-410004,13568-13835$ cal yr BP), shows that the sedimentary contribution to the ND was produced by suspension (Höbig et al., 2012). It also shows that the aqueous medium contributed a large quantity of clays, some of which are associated with a temperate climate (kaolinite). This may seems paradoxical, since the dating performed at a depth of $16 \mathrm{~m}$ depth is within the Heinrich event $1(\mathrm{H} 1)$ cold stage. However, according to Naughton et al. (2007) during $\mathrm{H} 1$ temperature contrasts between the ocean and the continent may appear in the same time-period, which is also reflected in the contrasts between continental and marine sedimentary records. Between 18 and 17.3 ka BP major sedimentary changes in glacial related paleolakes in the Pyrenees and Cantabrian mountains (Jalut et al. 2010) correlate with an increase 
of $\delta 180$ in the NGRIP ice-core record, between 18.5 and 17.5 ka (Lowe et al., 2008; Rasmussen et al., 2014). Railsback et al. (2017) in the Serra do Courel (NW Spain), also obtain data from stalagmite ESP06 $\delta 180-\delta 13 \mathrm{C}$ indicating a marked shift from dry, cold conditions $(\delta 13 C=-5.6)$ to a wetter, warmer climate $(\delta 13 C=-7.5)$ at the onset of $18 \mathrm{ka}(\mathrm{U} / \mathrm{Th}$ age series). $\delta 13 \mathrm{C}$ values from ESP06 stalagmite also oscillate between 7.5 and -5.6 at the onset of $15 \mathrm{ka}$ (U/Th age series; Railsback et al., 2011). Isotopic shifting from Serra do Courel ESP06 stalagmite agrees with Jalut's findings between 15 and $13.3 \mathrm{ka}$ in the glacial paleolakes in the Pyrenees and the Cantabrian mountain range. In fact, Jalut et al. (2010), describe major sedimentary changes synchronous with a climatic improvement recorded between the end of the Oldest Dryas (GS-2a) and the end of the Bølling-Allerød period ( $\mathrm{Gl}-1 \mathrm{e}, \mathrm{Gl}-1 \mathrm{~d}$, and $\mathrm{Gl}-1 \mathrm{c})$. All this seems to indicate that the ND was also affected by the improved climate during the Bølling, when the kaolinite contribution occurred at the bottom of the lake in the ND, while the context of the glacial fronts in the north of the Iberian Peninsula (Jalut et al., 2010) is one of final retreat.

The separation between the Bølling and the Allerød is represented by the Older Dryas (Watts et al., 1996), with sedimentation consisting of dark greenish-brown clays with plant macroremains between 15.62-15.76 m depth (GI-1d; 14000 cal yr BP, see Fig. 3C). During this interval, a relative MS peak is also detected (label 17, see Fig. $3 G$ ), and may correspond to some mineralization from possible sub-aerial exposure or incipient paleosol formation. The LOI record started at this stage in the ND and moderate LOI values are obtained (see Fig. 3K; label OD = Older Dryas). The Older Dryas has rarely been documented in Northern Spain (Jalut et al., 2010) and to date in the Mediterranean mountains (Hughes and Woodward, 2017). However, Carrasco et al., (2015a) reported new exposure ages from moraines dated to the Older Dryas.

650 During this stage, sedimentation in the ND was sub-aerial, with no permanent water sheet, as it changed from lacustrine clays to initial hydromorphic soil sedimentation (see Fig. 3F). 

$13568-13835$ cal yr BP and Holocene; $\beta-410003,11264-11619$ cal yr BP) is an overall shallowing sequence (see Fig. 3F), but extremely complicated from a climatic viewpoint. It has therefore been subdivided into four climatic groups of paleoclimatically similar layers.

658 Group 1. 15.62-15.43 m depth (GI-1c; Allerød) the colour of the clay sediments is different from the previous segment (15.62-15.76 m). Here the clays are greyer and more massive. Between 15.43 m-15.00 m depth (GI-1c; 13500-13250 cal yr BP; see Fig. 4) the sedimentation is composed of organic clays associated with hydromorphic soils. These silts present green-grey colouring typical of reductive sedimentary conditions. The discoloration of these sediments occurs when the redox potential is low and there is leaching by the phreatic surface of chromogenic compounds such as $\mathrm{Fe}$ and Mg (Mingarro and Ordoñez, 1982). To the existence of this process, there must be permanent presence of phreatic water, which implies a humid climate for the Allerød in ND, as noted by Moreno et al. (2010) in the northern Cantabrian range. The increased LOI in this segment is evident (see Fig. 3K), with the presence of the first sedimentary charcoals (see Fig. 3J; label $A=$ Allerød). At near $15.00 \mathrm{~m}$ depth a significant LOI reduction is observed and also the disappearance of sedimentary charcoal (see Fig. $3 \mathrm{~J}$ and $3 \mathrm{~K}$ ), which may be linked to the Intra Allerød Cold Period (IACP); von Grafenstein et al., 1999).

Group 2. A change in the sediment regime is observed at $14.95 \mathrm{~m}$ depth (GI-1b; 13250 cal yr BP). On the one hand, at $14.95 \mathrm{~m}$ depth there is a significant reduction in MS (label 16, see Fig. 3G), and a very important increase in the LOI (see Fig. 3K), already initiated before $15.00 \mathrm{~m}$ depth. A greater abundance of organic matter gives the sediments a dark brown colour, and they are interpreted as from a marshy environment. In the Serra do Courel (O Courel, ESP05 and ESP06; Railsback et al., 2011), migration is suspected towards positive values of $\delta 13 \mathrm{C}(-5.7<\delta 13 \mathrm{C}<-5.4)$ 
681 with the sustained increase of LOI and sedimentary charcoals throughout this period 682 (see Fig. 3J) suggesting wetter conditions (Daniau et al., 2007). Between 14.95-14.19 m depth (13250 - 12250 cal yr BP; see Fig. 3C) belongs to the late Allerød (GI-1a) and early Younger Dryas (GS-1). In contrast to what is observed in the northern Iberian Peninsula, (Jalut et al., 2010), the end of the Allerød and onset of the Younger Dryas present similar environmental conditions, with only the Intra Allerød Cold Period (IACP) marking the separation between the two. In Serra do Courel (O Courel, ESP05) the section dated between 13123-8291 yr (U/Th age series) by Railsback et al. (2017) presents a minimum value of $\delta 13 \mathrm{C}(-6.7)$, indicating wet conditions for the NW sector of the Iberian Peninsula.

Group 3. The second part of the Younger Dryas is represented in section 14.0-13.50 m depth (GS-1; 12250-11500 cal yr BP; see Fig. 4) with a first progradation of coarse grain facies and presence of charcoal macroremains (see Fig. $3 \mathrm{~J}$ ) in parallel to the LOI (see Figs. 3J and 3K). The coldest and most arid part of the Younger Dryas may perhaps correspond to the LOI minimum and charcoals observed near depth $14.50 \mathrm{~m}$ depth (label YD; see Fig. 3K). In the western part of the Iberian Range (E Spain) the Younger Dryas is described as an arid period by Vegas (2006). Group 4. Segment 13.03-13.61 m depth (11000-11500 cal yr BP; see Fig. 4) is formed of medium grain sand mixed with dark brown silt. This section is included in the same sediment rate as the groups above and precedes the onset of the Holocene (11603 cal yr BP; Lowe et al., 2008; Rasmunssen et al., 2014; Walker et al., 2009). The group forms a fining-upward sequence, similar to that observed in other glacial valleys (Riera and Turu, 2011) which have experienced recurrent paleofires. The burnings may have promoted transformation of iron oxides into their ferromagnetic form (Tite and Linington, 1975), which may increase the MS value (label 15; see Fig. 3G). On the other hand, in climatic periods with alternating dry/wet cycles, the organic matter promotes reduction of bacterial detrital iron oxides and facilitates chemical precipitation of ultrafine magnetite (Verosub et al., 1993), increasing the MS signal. 


\subsection{The Holocene}

711

The onset of the Holocene occurred with an important sediment rate (12.645 $\mathrm{mm} / \mathrm{yr})$ between 13.3-7.86 m depth $(\beta-410003,11264-11619$ cal yr BP and $\beta-410001$, 10949-11072 cal yr BP). This sediment rate considerably exceeds earlier rates, but is usual in a channel type sedimentary context (5th-order surfaces from Miall, 1991). Given that there is no evidence of embankments in the ND, the sediment contribution could not have originated in crevasse splay-type flooding. In these conditions, the formation of the upper sedimentary layers is interpreted as an entrenched filling process. The channel incision must have formed during a base level change (level 13.1 m, Unconformity Surface, US; see Fig. 3I). Based on data obtained using geophysical methods (Carrasco et al., 2015b), active tectonics is suggested as the possible origin of the base level change in the ND around 11400 cal yr BP $(\beta-410003)$.

In the next segment, between 7.86-7.00 m depth ( $\beta-410001,10949-11072 \mathrm{cal}$ yr BP and $\beta-410000,10626-10746$ cal yr BP), the sedimentation rate falls considerably to $2.69 \mathrm{~mm} / \mathrm{yr}$ (Fig. 3A). Diatom communities indicate a water deficit at that time (Leira, 2000), contemporary with arid phases described in the western Mediterranean around 10900-9700 Cal. BP (Jalut et al., 2000). depth ( $\beta-410000,10626-10746$ cal yr BP and $\beta-409999 ; 6272-6324$ cal yr BP) the sedimentation rate is one order of magnitude lower than the previous rate $(0.24$ $\mathrm{mm} / \mathrm{yr}$ ), remaining within the alluvial fan-type depositional systems (Miall, 1991). Isotopic stability of ESP05 stalagmite (Railsback et al., 2011) before $6670 \mathrm{yr}$ (U/Th age series) also indicates stability in the climatic context of the NW of the Iberian Peninsula, warm and wet $\delta 13 \mathrm{C}(=-6.4)$ before $6670 \mathrm{yr}(\mathrm{U} / \mathrm{Th}$ age series). Pollen sequences from

734 Sierra de Guadarrama (ICS) show continental climatic conditions and an absolute predominance of Pinus (Franco-Múgica et al., 1998). 

50407, respectively; see Table 1), there is some inversion of AMS data related to the sedimentary process. In both cases, the sediment samples correspond to sandy loam layers of similar ages. We interpret this inversion as the result of a scour and fill sedimentary process. The appearance of charcoals (Fig. 3J) is interpreted from their coarsening-upward trend (see Fig. 3E) as the product of paleoburnings (Riera and Turu, 2011). The rapid erosion and scour infill of the previous deposits, originate a lastin/first-out dumping sedimentary process. In ESP05 stalagmite (Railsback et al., 2011) a more positive $\delta 13 \mathrm{C}$ value was obtained than previously $(\delta 13 \mathrm{C}=-3.2)$ before $5126 \mathrm{yr}$ (U/Th age series), showing especially arid conditions in the NW Iberian Peninsula. In the Serra da Estrela (ICS), van der Knaap and van Leeuwen (1995) indicate that around 6000/6300 cal-yr BP the landscape changed (Erica increased). In the following segment, between $4.75 \mathrm{~m}$ depth in S0 and $1.59 \mathrm{~m}$ depth in S3 2007). At the same time, a dramatic fall in arboreal pollen (AP) occurs at $4142-4104$ 2010) ends at 3900 cal yr BP, suggesting since then both a limited water supply and possible interruptions in the sedimentation and erosion processes. In the Serra do Courel (ESP05 stalagmite; Railsback et al., 2011) the $\delta 13 \mathrm{C}$ value indicates especially humid conditions for the NW Iberian Peninsula during a period of nearly $3000 \mathrm{yr}$ (U/Th age series), since the $\delta 13 \mathrm{C}$ value is the most negative logged $(\delta 13 \mathrm{C}=-6.9)$. 

cal-yr BP. The ESP05 record from the NW of the Peninsula shows a more positive value $(\delta 13 \mathrm{C}=-5)$ around $2000 \mathrm{yr}(\mathrm{U} / \mathrm{Th}$ age series) indicating lower humidity (Railsback et al., 2011). Nevertheless, in the ND the LOI remains constant between 2 and $3 \mathrm{~m}$, with a no evident reduction in the production of organic matter (Fig. $3 \mathrm{~K}$ ).

Finally, a few hundred years before the present the $\delta 13 \mathrm{C}$ value again becomes more negative $(\delta 13 C=-6.9)$, and therefore there is a relative improvement in the climate, by now in the historic period (U/Th age series). In the ND the LOI oscillates (see Fig 3K), obtaining a minimum value at depths between 1.1 and $0.8 \mathrm{~m}$ depth, which may coincide with the Dark Ages Cold Period (McDermott et al., 2001).

\section{Synthesis and conclusions}

The ice and border deposits build-up from Cuerpo de Hombre glacier (PD-B; see Fig. 5), may have initiated glaciolacustrine sedimentation in the ND at $25.0 \pm 1.3 \mathrm{ka}$ BP. During these stages, weather patterns were dominated by a southerly airflow due to displacement of the oceanic polar front towards the south (Florineth and Schlüchter, coast of the Iberian Peninsula. Atmospheric circulation may have fed the eastern side of Sierra de Béjar by snow deflation due to strong westerly winds in the first half of Heinrich event 1. Then a second glacial advance occurred at 20.6-17.8 ka BP (Carrasco et al., 2015a) with the build-up of the PM moraine (see Fig. 5), probably produced by a surge-like advance of the glacier by snow/firn overaccumulation on the Cuerpo de Hombre summit, as similar mechanisms act in modern glaciers (Jamieson et al., 2015). For example, in the Pyrenean-Cantabrian mountain range the stage 
between $\sim 32$ and $16 \mathrm{ka}$ is considered as one of general readvances, possibly associated with "surge-event" type processes (Jalut et al., 2010). The second half of the Heinrich event 1 was a dry period and the atmospheric circulation was mainly dominated by northern drier, colder winds (Naughton et al., 2009). That would have consolidated the development of thermally colder glaciers with larger volume but smaller extension than in the preceding stage, and the build-up of the ID-M2/M1 moraines in the Cuerpo de Hombre valley (see Fig. 5).

The ND core sequence between 16.0 and $13.03 \mathrm{~m}$ depth closely matches the northern Europe sequence (Mangerud et al., 1974), with the succession of cold/warm events (stadials-interstadials); here the Older Dryas, the Allerød, the Intra Cold Allerød Period and the Younger Dryas and the Holocene. Naughton et al. (2007) remark a marked synchrony between the vegetation responses to the north Atlantic climate variability during this period (Bølling/Allerød - Younger Dryas). Carrasco et al. (2015a) conclude that the evolution of the Cuerpo de Hombre valley-type glacier presents notable affinities with the glaciers in the northernmost regions of Europe until the IACP (13.1 $\pm 1.2 \mathrm{ka})$. However, wet to dry asymmetry phases in the eastern North Atlantic from changes in the position of the Atlantic jet-stream were described by Naughton et al. (2009), for three of the last four Heinrich events (H4, H2 and H1). However, in ND that wet/dry asymmetry is also observed for the Younger Dryas $(\mathrm{H} 0)$.

Moisture from oceanic westerly winds is consistent with the climatic trend throughout the ICS, and is responsible for the build-up of the ID-M3 moraine in the Cuerpo de Hombre valley (see Fig. 5). On the one hand, palynological studies by van

813 Sierra de Béjar), match the late $\mathrm{CH}$ paleoglacier sequence (Carrasco et al., 2015 a).

814 On the other hand, conditions were drier towards the eastern ICS. In the Sierra de 815 Gredos (47 km E) and Sierra de Guadarrama (163 km NE), glacier tongues 816 disappeared $\sim 15 \mathrm{ka}$ and only residual cirques or rocky glaciers remained until $\sim 10 \mathrm{ka}$ 817 (Palacios et al., 2011, 2012a, 2012b). The last moraine build-up in the upper part of the 
818 Cuerpo de Hombre valley (ID-M4; see Fig. 5) defined the $\mathrm{CH}$ cirque-type glacier stage, ending at the onset of the Holocene $(11.1 \pm 1.1 \mathrm{ka})$. The extremely high sedimentary rate between 13.03 and $7.86 \mathrm{~m}$ depth in ND is compatible with wetter conditions; nevertheless, the active tectonic imprint cannot be discarded in this period (Carrasco et al., 2015b).

The final retreat and disappearance of the $\mathrm{CH}$ paleoglacier is followed by the reactivation of periglacial and paraglacial slope processes, shown here by the important development of rock avalanches (Carrasco et al., 2013). Arid phases in the western Mediterranean around 10900-9700 cal yr BP (Jalut et al., 2000), are mainly responsible for the lower sedimentary rates in the ND between 7.86 and $4.75 \mathrm{~m}$ depth (11000 cal yr BP - 6300 cal yr BP; see Fig. 4).

A W-E moisture gradient across the ICS seems to have occurred in the early Holocene. In the westernmost ICS (Serra da Estrela; van der Knaap and van Leeuwen, 1995) Pinus does not predominate in the Holocene, a succession from xerothermic to mesothermic oak forest resulted from a wetter climate about 8000 yr ago (Pérez-Obiol, et al, 2011). Pollen sequences from the eastern ICS show continental climatic conditions (Franco-Múgica et al., 1998), and an absolute predominance of Scots Pine forest until 4142-4104 cal yr BP in Sierra de Guadarrama (Pérez-Obiol et al., 2011). The Sierra de Bejar was not immune to that influence and from its geographical

837 location, in climatic terms occupied a position mid-way between these two extreme moisture situations.

Shifting moisture gradients also seem to have occurred across the western central and northwestern Iberian Peninsula in the second half of the Holocene

841 (Railsback et al., 2011). This climatic relationship anti-phase during the Holocene is not specific to the Iberian Peninsula. It may have extended to Central Europe (Rius et al., 2011), possibly modulated by an NAO-like climate mechanism. (Vannière et al., 2011). 
This work was supported by the Spanish Ministry of Economy and Competitiveness

847 (Projects CGL2013-44076-P and CGL2016-78380-P). The authors also wish to acknowledge the help and assistance of the Regional Environment Department (JCyL) and the Local Authority in the village of Candelario.

850

\section{References}

Abel-Schaad, D., Pulido, F., López-Sáez, J.A., Alba Sánchez, F., Nieto Lugilde, D., Franco Múgica, F., Pérez-Díaz, S., Ruiz Zapata, M.B., Gil García, M.J., Dorado

AEMET/IM, 2011. Atlas Climático Ibérico-iberian Climate Atlas. AEMET and IM, Madrid. http://www.aemet.es/es/divulgacion/publicaciones/.

Aranbarri, J., González-Sampériz, P., Valero-Garcés, B., Moreno, A., Gil-Romera, G., Sevilla-Callejo, M., García-Prieto, E., Di Rita, F., Mata, M.P., Morellón, M., Magri, D., Rodríguez-Lázaro, J., Carrión, J.S., 2014. Rapid climatic changes and resilient vegetation during the Lateglacial and Holocene in a continental region of south-western Europe. Glob. Planet. Change 114, 50-65.

Atienza, M., 1993. Evolución del paisaje vegetal en las Sierras de Béjar y Francia durante el Holoceno, a partir del análisis polínico. Ph.D. Thesis, Alcalá de Henares Univ., Spain.

Breuer, S., Kilian, R., Baeza, O., Lamy, F., Arz, H., 2013. Holocene denudation rates from the superhumid southernmost Chilean Patagonian Andes (53ㅇ) deduced from lake sediment budgets. Geomorphology 187, 135-152.

Brown, K.J., Pasternack, G.B., 2004. The geomorphic dynamics and environmental history of an upper deltaic floodplain tract in the Sacramento-San Joaquin Delta, California, USA. Earth Surf. Process. Landforms 29, 1235-1258. 
872 Bullón, T., 2016. The upper Pleistocene on the northern face of the Guadarrama Mountains (Central Spain): Palaeoclimatic phases and glacial activity. Geomorphology 268, 233-245.

Calvet, M., 2004. The Quaternary glaciation of the Pyrenees. Dev. Quat. Sci. 2, 119128.

Carcaillet, C., Bouvier, M., Fréchette, B., Larouche, C., Richard, P.J.H., 2001. Comparison of pollen-slide and sieving methods in lacustrine charcoal analyses for local and regional fire history. The Holocene 11, 467-476.

Carcaillet, C., Bergman, I., Delorme, S., Hornberg, G., Zackrisson, O., 2007. Long-term

Carrasco, R.M., Pedraza, J., Domínguez-Villar, D., Muñoz-Rojas, J., 2008. El fire frequency not linked to prehistoric occupations in northern Swedish boreal forest. Ecology 88, 465-477.

Carrasco, R.M., Pedraza, J., Domínguez-Villar, D., Willenbring, J.K., Villa, J., 2013. 888 glaciarismo Pleistoceno de la Sierra de Béjar (Gredos occidental, Salamanca, España): nuevos datos para precisar su extensión y evolución. Bol. R. Soc. Esp. Hist. Nat. 102, 35-45. Supraglacial debris supply in the Cuerpo de Hombre paleoglacier (Spanish Central System): Reconstruction and interpretation of a rock avalanche event. Geogr. Ann. Ser. A Phys. Geogr. 95, 211-226.

Carrasco, R.M., Pedraza, J., Domínguez-Villar, D., Willenbring, J.K., Villa, J., 2015a. Sequence and chronology of the Cuerpo de Hombre paleoglacier (Iberian Central System) during the last glacial cycle. Quat. Sci. Rev. 129, 163-177.

Carrasco, R.M., Sánchez, J., Muñoz-Martín, A., Pedraza, J., Olaiz, A.J., Ruiz-Zapata, B., Abel-Schaad, D., Merlo, O., 2015b. Caracterización de la geometría de la depresión de Navamuño (Sistema Central Español) aplicando técnicas geofísicas. Geogaceta 57, 39-42.

Catuneanu, O., 2006. Principles of Sequence Stratigraphy, Changes. Elsevier Science, Amsterdam (Netherlands), $375 \mathrm{pp}$. 
Chamley, H., 1989. Clay Sedimentology, Spinger, Berlin, 623 pp.

901

902

903

904

905

906

907

908

909

910

911

912

913

914

915

916

917

918

919

920

921

922

923

924

925

Cserkész-Nagy, Á., Sztanó, O., 2016. Millennial-scale climatic fluctuation in the fluvial record during MIS3: Very high-resolution seismic images from NE Hungary. Geomorphology 274, 116-128.

Daniau, A.L., Sánchez Goñi, M.F., Beaufort, L., Laggoun-Defarge, F., Loutre, M.-F., Duprat, J., 2007. Dansgaard-Oeschger climatic variability revealed by fire emissions in southwestern Iberia. Quat. Sci. Rev. 26, 1369-1383.

Dean, W.E.J., 1974. Determination of carbonate and organic matter in calcareous sediments and sedimentary rocks by loss on ignition: Comparison with other methods. J. Sediment. Petrol. 44, 242-248.

Delmas, M., 2015. The last maximum ice extent and subsequent deglaciation of the Pyrenees: an overview of recent research. Cuadernos de Investigación Geográficas 41, 359-387

Domínguez-Villar, D., Carrasco, R.M., Pedraza, J., Cheng, H., Edwards, R.L., Willenbring, J.K., 2013. Early maximum extent of paleoglaciers from Mediterranean mountains during the last glaciation. Sci. Rep. 3.

El-Kadi, A.I., Plummer, L.N., Aggarwal, P., 2011. NETPATH-WIN: An interactive user version of the mass-balance model, NETPATH. Ground Water 49, 593-599.

Finsinger, W., Kelly, R., Fevre, J., Magyari, E.K., 2014. A guide to screening charcoal peaks in macrocharcoal-area records for fire-episode reconstructions. The Holocene 24, 1002-1008.

Florineth, D., Schlüchter, C., 2000. Alpine Evidence for Atmospheric Circulation Patterns in Europe during the Last Glacial Maximum. Quat. Res. 54, 295-308.

Franco-Múgica, F., Antón, M.G., Ollero, H.S., 1998. Vegetation dynamics and human impact in the Sierra de Guadarrama, Central System, Spain. The Holocene 8, 69-82. 
García-Ruiz, J.M., Valero-Garcés, B.L., Martí-Bono, C., González-Sampériz, P., 2003. Asynchroneity of maximum glacier advances in the central Spanish Pyrenees. J. Quat. Sci. 18, 61-72.

García-Ruiz, J.M., Moreno, A., González-Sampériz, P., Valero-Garcés, B., Martí-Bono, C., 2010. La cronología del último ciclo glaciar en las montañas del sur de Europa. Una revisión. Cuaternario y Geomorfología 24, 35-46.

Gebica, P., Sokolowski, T., 2001. Sedimentological interpretation of crevasse splays formed during 1997 flood in the Vistula River Valley (South Poland). An. Soc. Geol. Pol. 71, 53-62.

Génova, M., Gómez-Manzaneque, F., Martínez-García, F., Postigo-Mijarra, J.M., 2016. Early Holocene vegetation in the Ayllón Massif (Central System Range, Spain) based on macroremains. A paleoecological approach. Palaeogeogr. Palaeoclimatol. Palaeoecol. 441, 811-822.

Gómez-Ortiz, A., Palacios, D., Palade, B., Vázquez-Selem, L., Salvador-Franch, F., 2012. The deglaciation of the Sierra Nevada (Southern Spain). Geomorphology 159-160, 93-105.

González-Sampériz, P., Valero-Garcés, B.L., Moreno, A., Jalut, G., García-Ruiz, J.M., Martí-Bono, C., Delgado-Huertas, A., Navas, A., Otto, T., Dedoubat, J.J., 2006. Climate variability in the Spanish Pyrenees during the last $30,000 \mathrm{yr}$ revealed by the El Portalet sequence. Quat. Res. 66, 38-52.

González-Sampériz, P., Aranbarri, J., Pérez-Sanz, A., Gil-Romera, G., Moreno, A., Leunda, M., Sevilla-Callejo, M., Corella, J.P, Morellón, M., Oliva., ValeroGarcés, B., 2017. Environmental and climate change in the southern Central Pyrenees since the Last Glacial Maximum: A view from the lake records. Catena 149, 668-688.

Harrison, S.P., Digerfeldt, G., 1993. European lakes as palaeohydrological and palaeoclimatic indicators. Quat. Sci. Rev. 12, 233-248. 
Höbig, N., Weber, M.E., Kehl, M., Weniger, G.C., Julià, R., Melles, M., Fülöp, R.H., Vogel, H., Reicherter, K., 2012. Lake Banyoles (northeastern Spain): A Last Glacial to Holocene multi-proxy study with regard to environmental variability and human occupation. Quat. Int. 274, 205-218.

Hughes, P. D., Woodward, J. C., 2008. Timing of glaciation in the Mediterranean mountains during the last cold stage. J. Quat. Sci. 23, 575-588.

Hughes, P.D., Woodward, J.C., 2017. Quaternary glaciation in the Mediterranean mountains: a new synthesis. Geological Society, London, Special Publications $433,1-23$.

Jalut, G., Marti, J.M., Fontugne, M., Delibrias, G., Vilaplana, J.M., Julia, R., 1992. Glacial to interglacial vegetation changes in the northern and southern Pyrénées: Deglaciation, vegetation cover and chronology. Quat. Sci. Rev. 11, 449-480.

Jalut, G., Esteban Amat, A., Bonnet, L., Gauquelin, T., Fontugne, M., 2000. Holocene climatic changes in the Western Mediterranean, from south-east France to south-east Spain. Palaeogeogr. Palaeoclimatol. Palaeoecol. 160, 255-290.

Jalut, G., Turu i Michels, V., Dedoubat, J.J., Otto, T., Ezquerra, J., Fontugne, M., Belet, J.M., Bonnet, L., de Celis, A.G., Redondo-Vega, J.M., Vidal-Romaní, J.R., Santos, L., 2010. Palaeoenvironmental studies in NW Iberia (Cantabrian range): Vegetation history and synthetic approach of the last deglaciation phases in the western Mediterranean. Palaeogeogr. Palaeoclimatol. Palaeoecol. 297, 330-350.

Jamieson, S.S.; Ewertowski, M.W.; Evans, D.J.A., 2015. Rapid advance of two mountain glaciers in response to mine-related debris loading. J. Geophys. Res. Earth Surfaces 120, 1-19.

Jiménez-Sánchez, M., Rodríguez-Rodríguez, L., García-Ruiz, J.M., DomínguezCuesta, M.J., Farias, P., Valero-Garcés, B., Moreno, A., Rico, M., Valcárcel, M., 2013. A review of glacial geomorphology and chronology in northern Spain: 
timing and regional variability during the last glacial cycle. Geomorphology 196, $50-64$.

Leira, M., 2000. Paleolimnología en lagos postglaciares del Noroeste de la Península Iberica. Ph.D. Thesis, Universidade de A Coruña, Spain.

Lewis, C.J., McDonald, E. V., Sancho, C., Peña, J.L., Rhodes, E.J., 2009. Climatic implications of correlated Upper Pleistocene glacial and fluvial deposits on the Cinca and Gállego Rivers (NE Spain) based on OSL dating and soil stratigraphy. Glob. Planet. Change 67, 141-152.

López-Sáez, J.A., Abel-Schaad, D., Pérez-Díaz, S., Blanco-González, A., AlbaSánchez, F., Dorado, M., Ruiz-Zapata, B., Gil-Garcáa, M.J., Gómez-González, C., Franco-Múgica, F., 2014. Vegetation history, climate and human impact in the Spanish Central System over the last 9000 years. Quat. Int. 353, 98-122.

López-Sáez, J. A., Abel-Schaad, D., Robles-López, S., Pérez-Díaz, S., Alba-Sánchez, F., Nieto-Lugilde, D., 2016. Landscape dynamics and human impact on highmountain woodlands in the western Spanish Central System during the last three millennia. J. Archaeol. Sci. Reports 9, 203-218.

Lowe, J.J., Rasmussen, S.O., Björck, S., Hoek, W.Z., Steffensen, J.P., Walker, M.J.C., Yu, Z.C., 2008. Synchronisation of palaeoenvironmental events in the North Atlantic region during the Last Termination: a revised protocol recommended by the INTIMATE group. Quat. Sci. Rev. 27, 6-17.

Luque, J.A., 2003. Lago de Sanabria: un sensor de las oscilaciones climáticas del Atlántico Norte durante los últimos 6.000 años. Ph.D. Thesis, Univ. de Barcelona, Barcelona, Spain.

Magny, M., Miramont, C., Sivan, O., 2002. Assesment of the impact of climate and anthropogenic factors on Holocene Mediterranean vegetation in Europe on the basis of palaeoecological records. Palaeogeogr. Palaeoclimatol. Palaeoecol.186, 47-59. 
Mangerud, J. a N., Andersen, S.T., Berglund, B.E., Donner, J.J., 1974. Quaternary stratigraphy of Norden, a proposal for terminology and classification. Boreas 3 , $109-126$.

McDermott, F., Mattey, D.P., Hawkesworth, C., 2001. Centennial-scale holocene climate variability revealed by a high-resolution speleothem delta O-18 record from SW Ireland. Science 294, 1328-1331.

Miall, A.D., 1991. Stratigraphic sequences and their chronostratigraphic correlation. J. Sediment. Res. 61, 497-505.

Mingarro, F., Ordóñez, S. 1982. Petrología Exógena I. Ed. Rueda, Madrid, 387pp.

Moreno, A., Valero-Garcés, B.L., Jiménez-Sánchez, M., Domínguez-Cuesta, M. J., Mata, M. P., Navas, A., González-Sampériz, P., Stoll, H., Farias, P., Morellón, M., Corella, J. P., Rico, M., 2010. A morphometric analysis of tunnel valleys in the eastern North Sea based on 3D seismic data. J. Quat. Sci. 25, 1076-1091.

Moreno, A., González-Sampériz, P., Morellón, M., Valero-Garcés, B.L., Fletcher, W.J., 2012. Northern Iberian abrupt climate change dynamics during the last glacial cycle: A view from lacustrine sediments. Quat. Sci. Rev. 36, 139-153.

Muhs, D.R., Lancaster, N., Skipp, G.L., 2017. A complex origin for the Kelso Dunes, Mojave National Preserve, California, USA: A case study using a simple geochemical method with global applications. Geomorphology 276, 222-243.

Naughton, F., Sanchez Goñi, M.F., Desprat, S., Turon, J.L., Duprat, J., Malaizé, B., Joli, C., Cortijo, E., Drago, T., Freitas, M.C., 2007. Present-day and past (last 25000 years) marine pollen signal off western Iberia. Mar. Micropaleontol. 62, $91-114$.

Naughton, F., Sánchez Goñi, M.F., Kageyama, M., Bard, E., Duprat, J., Cortijo, E., Desprat, S., Malaizé, B., Joly, C., Rostek, F., Turon, J.L., 2009. Wet to dry climatic trend in north-western Iberia within Heinrich events. Earth Planet. Sci. Lett. 284, 329-342. 
Palacios, D., Marcos, J. de, Vázquez-Selem, L., 2011. Last Glacial maximum and deglaciation of Sierra de Gredos, central Iberian Peninsula. Quat. Int. 233, 1626.

Palacios, D., de Andrés, N., Marcos, J., Vázquez-Selem, L., 2012a. Glacial landforms and their paleoclimatic significance in the Sierra de Guadarrama, Central Iberian Peninsula. Geomorphology 139-140, 67-78.

Palacios, D., Andrés, N., Marcos, J., Vázquez-Selem, L., 2012b. Maximum glacial advance and deglaciation of the Pinar Valley (Sierra de Gredos, Central Spain) and its significance in the Mediterranean context. Geomorphology 177-178, $51-61$.

Palacios, D., de Andrés, N., Gómez-Ortiz, A., García-Ruiz, J.M., 2017. Evidence of glacial activity during the Oldest Dryas in the mountains of Spain. Geological Society, London, Special Publications 433, 87-110.

Pedraza, J., Carrasco, R.M., Domínguez-Villar, D., Villa, J., 2013. Late Pleistocene glacial evolutionary stages in the Gredos Mountains (Iberian Central System). Quat. Int. 302, 88-100.

Perez-Obiol, R., Jalut, G., Julia, R., Pelachs, A., Iriarte, M.J., Otto, T., HernandezBeloqui, B., 2011. Mid-Holocene vegetation and climatic history of the Iberian Peninsula. The Holocene 21, 75-93.

Railsback, L.B., Liang, F., Vidal Romaí, J.R., Grandal-d'Anglade, A., Vaqueiro Rodríguez, M., Santos Fidalgo, L., Fernández Mosquera, D., Cheng, H., Edwards, R.L., 2011. Petrographic and isotopic evidence for Holocene longterm climate change and shorter-term environmental shifts from a stalagmite from the Serra do Courel of northwestern Spain, and implications for climatic history across Europe and the Mediterranean. Palaeogeogr. Palaeoclimatol. Palaeoecol. 305, 172-184.

Railsback, L.B., Liang, F., Vidal-Romaní, J.R., Garrett, K.B., Sellers, R.C., VaqueiroRodríguez, M., Grandal-d'Anglade, A., Cheng, H., Edwards, R.L., 2017. 
Radiometric, isotopic, and petrographic evidence of changing interglacials over the past 550,000 years from six stalagmites from the Serra do Courel in the Cordillera Cantábrica of northwestern Spain. Palaeogeogr. Palaeoclimatol. Palaeoecol. 466, 137-152.

Rasmussen, S.O., Bigler, M., Blunier, T., Buchardt, S.L., Clausen, H.B., Cvijanovic, I., Johnsen, S.J., Fischer, H., Gkinis, V., Guillevic, M., Hoek, W.Z., Lowe, J.J., Pedro, J., Popp, T., Seierstad, I.K., Steffensen, J.P., Svensson, a M., Vallelonga, P., Vinther, B.M., Wheatley, J.J., Winstrup, M., 2014. A stratigraphic framework for robust naming and correlation of abupt climatic changes during the last glacial period based on three synchronized Greenland ice core records. Quat. Sci. Rev. 106, 14-28.

Rea, D. K., Moore, T. C., Anderson, T. W., Lewis, C. M., Dobson, D. M., Dettman, D. L., Smith, A.J., Mayer, L.A., 1994. Great Lakes paleohydrology: complex interplay of glacial meltwater, lake levels, and sill depths. Geology 22, 10591062.

Reimer, P.J., Bard, E., Bayliss, A., Beck, J.W., Blackwell, P.G., Ramsey, C.B., 2013. IntCal13 and Marine13 Radiocarbon Age Calibration Curves 0-50,000 Years cal BP. Radiocarbon 55, 1869-1887.

Riera, S., Turu, V. 2011. Cambios en el paisaje del valle de Ordino al inicio del Holoceno: Evolución geomorfológica, paleovegetal e incendios de época Mesolítica (NW del Principado de Andorra, Pirineos Orientales). In: V. Turu, A. Constante-Orrios (Eds.). El Cuaternario en España y áreas afines, avances en 2011. Fundació Marcel Chevalier-AEQUA, Andorra la Vella, 201-205.

Rius, D., Vannière, B., Galop, D., Richard, H., 2011. Holocene fire regime changes from multiple-site sedimentary charcoal analyses in the Lourdes basin (Pyrenees, France). Quat. Sci. Rev. 30, 1696-1709.

Rodríguez-Rodríguez, L., Jiménez-Sánchez, M., Domínguez-Cuesta, M.J., Rico, M.T., Valero-Garcés, B., 2011. Last deglaciation in northwestern Spain: New 
chronological and geomorphologic evidence from the Sanabria region. Geomorphology 135, 48-65.

1093

1094

1095

1096

1097

1098

1099

1100

1101

1102

1103

1104

1105

Rodríguez-Rodríguez, L., Jiménez-Sánchez M., Domínguez-Cuesta, M.J., Aranburu, A., 2015. Research history on glacial geomorphology and geochronology of the Cantabrian Mountains, north Iberia (43-42 N/7-2 $\mathrm{W})$. Quat. Int. 364, 6-21.

Roucoux, K.H., De Abreu, L., Shackleton, N.J., Tzedakis, P.C., 2005. The response of NW Iberian vegetation to North Atlantic climate oscillations during the last 65 kyr. Quat. Sci. Rev. 24, 1637-1653.

Rubiales, J.M., García-Amorena, I., Génova, M., Gómez Manzaneque, F., Morla, C., 2007. The Holocene history of highland pine forests in a submediterranean mountain: the case of Gredos mountain range (Iberian Central range, Spain). Quat. Sci. Rev. 26, 1759-1770.

Ruddiman, F.W., Mclntyre, A., 1981. The North Atlantic Ocean during the last deglaciation. Palaeogeogr. Palaeoclimatol. Palaeoecol. 35, 145-214.

Ruiz-Zapata, M.B., Acaso-Deltell, E., 1981. Contribución al estudio del cuadro vegetal y climático durante el Cuaternario reciente en el Macizo Central de Gredos (Ávila). Bol. R. Soc. Esp. Hist. Nat. 79, 299-307.

Ruiz-Zapata, M.B., Acaso-Deltell, E., 1984. Clima y vegetación durante el Cuaternario reciente en el Macizo Central de Gredos (Ávila). In: I Congreso Nacional de Geología. Colegio de Geólogos, Madrid, pp. 723-740.

Ruiz-Zapata, M.B., Andrade, A., Gil-García, M.J., Dorado, M., Atienza, M., 1996. Evolución de la vegetación en los últimos 6000 años en los sectores Central y Oriental del Sistema Central Español. Revista Española de Paleontología número extraordinario, 288-298.

Ruiz-Zapata, M.B., Carrasco, R.M., Gil-García, M.J., De, J., Razola, L., Domínguezvillar, D., Gallardo, J.L., 2011. Dinámica de la vegetación durante el Holoceno en la Sierra de Gredos (Sistema Central Español). Bol. R. Soc. Esp. Hist. Nat. $105,109-123$. 
Sánchez-López, G., Hernández, A., Pla-Rabes, S., Trigo, R.M., Toro, M., Granados, I., Sáez, A., Masqué, P., Pueyo, J.J., Rubio-Inglés, M.J., Giralt, S., 2016. Climate reconstruction for the last two millennia in central Iberia: The role of East Atlantic (EA), North Atlantic Oscillation (NAO) and their interplay over the Iberian Peninsula. Quat. Sci. Rev. 149, 135-150.

Sanglerat, G., 1967. El Penetrómetro y el Reconocimiento de los Suelos. Min. de Obras Públicas, Madrid, Spain.

Sartori, M., Heller, F., Forster, T., Borkovec, M., Hammann, J., Vincent, E., 1999. Magnetic properties of loess grain size fractions from the section at Paks (Hungary). Phys. Earth Planet. Inter. 116, 53-64.

Serrano, E., González-Trueba, J.J., González-García, M., 2012. Mountain glaciation and paleoclimate reconstruction in the Picos de Europa (Iberian Peninsula, SW Europe). Quat. Res. (United States) 78, 303-314.

Serrano, E., González-Trueba, J.J., Pellitero, R., González-García, M., Gómez-Lende, M., 2013. Quaternary glacial evolution in the Central Cantabrian Mountains (Northern Spain). Geomorphology 196, 65-82.

Serrano, E., Gonzalez-Trueba, J.J., Pellitero, R., Gomez-Lende, M. 2017. Quaternary glacial history of the Cantabrian Mountains of northern Spain: a new synthesis. Geological Society, London, Special Publications 433, 55-85.

Singer, M.J., Verosub, K.L., Fine, P., TenPas, J., 1996. A conceptual model for the enhancement of magnetic susceptibility in soils. Quat. Int. 34-36, 243-248.

Tite M. S., Linington R. E., 1975. Effect of climate on magnetic susceptibility of soils. Nature 256, 565-566.

Turu, V., Calvet, M., Bordonau, J., Gunnell, Y., Delmas, M., Vilaplana, J. M., Jalut, G., 2017. Did Pyrenean glaciers dance to the beat of global climatic events? Evidence from the Würmian sequence stratigraphy of an ice-dammed palaeolake depocentre in Andorra. Geological Society, London, Special Publications 433, 111-136. 
van der Knaap, W.O., van Leeuwen, J.F.N., 1997. Late Glacial and early Holocene vegetation succession, altitudinal vegetation zonation, and climatic change in the Serra da Estrela, Portugal. Rev. Palaeobot. Palynol. 97, 239-285.

Vannière, B., Power, M.J., Roberts, N., Tinner, W., Carrión, J., Magny, M., Bartlein, P., Colombaroli, D., Daniau, A.L., Finsinger, W., Gil-Romera, G., Kaltenrieder, P., Pini, R., Sadori, L., Turner, R., Valsecchi, V., Vescovi, E., 2011. CircumMediterranean fire activity and climate changes during the mid-Holocene environmental transition (8500-2500 cal. BP). The Holocene 21, 53-73.

Vegas, J., 2006. Los sistemas lacustres de las sierras de Neila y Urbión. Análisis sedimentológico y climático del Pleistoceno superior y Holoceno. Ph.D. Thesis, Complutense Univ., Spain.

Verosub, K.L., Fine, P., Singer, M.J., Tenpas, J., 1993. Pedogenesis and paleoclimate: interpretation of the magnetic susceptibility record of Chinese loess-paleosol sequences. Geology 21, 1011-1014.

Vidal-Romaní, J.R., Fernández-Mosquera, D., 2006. Glaciarismo pleistoceno en el NW de la Península Ibérica (Galicia, España-Norte de Portugal). Enseñanza de las Ciencias la Tierra 13, 270-277.

Vieira, G., Ferreira, A.B., Mycielska-Dowgiallo, E., Woronko, B., Olszak, I., 2001. Thermoluminescence Dating of Fluvioglacial Sediments (Serra da Estrela, Portugal). V REQUI/I CQPLI, Lisboa, Portugal, 85-92.

Villaseca, C., 2003. Sobre el origen del batolito granítico del Sistema Central Español. Bol. R. Soc. Esp. Hist. Nat. 98, 23-39.

Villaseca, C., Barbero, L., Herreros, V., 1999. Types in Intracontinental Orogenic Belts. Trans. R. Soc. Edinb. Earth Sci. 89, 113-119.

von Grafenstein, U., Erlenkeuser, H., Brauer, A., Jouzel, J., Johnsen, S. J. 1999. A mid-European decadal isotope-climate record from 15,500 to 5000 years BP. Science 284(5420), 1654-1657. 
Walker, M., 2005. Quaternary dating methods. John Wiley \& Sons, Ltd (Eds.), West Susex, England.

Walker, M., Johnsen, S., Rasmussen, S. O., Popp, T., Steffensen, J.-P., Gibbard, P., Hoek, W., Lowe, J., Andrews, J., Björck, S., Cwynar, L. C., Hughen, K., Kershaw, P., Kromer, B., Litt, T., Lowe, D. J., Nakagawa, T., Newnham, R., and Schwander, J., 2009. Formal definition and dating of the GSSP (Global Stratotype Section and Point) for the base of the Holocene using the Greenland NGRIP ice core, and selected auxiliary records. J. Quaternary Sci. 24, 3-17.

Watts, W. A., Allen, J. R. M., Huntley, B., Fritz, S. C., 1996. Vegetation history and climate of the last 15,000 years at Laghi di Monticchio, southern Italy. Quaternary Science Reviews 15(2), 113-132.

Wolfe, AP; Kaushal, S.S.; Fulton J.R.; McKnight D.M. 2002. Spectrofluorescence of sediment humic substances and historical changes of lacustrine organic matter provenance in response to atmospheric nutrient enrichment. Environ. Sci. Technol. 36(15), 3217-23. 
Fig. 1. A) Location of Navamuño depression on the Iberian Central System context. B)

3D image of the Navamuño depression and Cuerpo de Hombre paleoglacier using ArcScene 10.4 and PNOA-2014 orthophoto (http://www.ign.es).

Fig. 2. A) Geomorphological mapping of Navamuño depression and surroundings. B)

Panoramic view of Navamuño photographed from its SE boundary facing NW.

Fig. 3. A) Laboratory AMS chronology in BP calibrated calendar years and related sedimentation rate (in $10^{-3} \mathrm{~m} / \mathrm{yr}$ ). B) Sedimentary Facies code: $\mathrm{Gm}$, gravel, massive or crudely bedded (lags, point bars); SI, sands, laminated (scour fill); Sp, sands, planar crossbed; Sh, sands, horizontal bedding; St, sand, crossbed (though); Ss, sand, scour fills, erosive contact; Fm, fines (silt, clay) massive (overbank); FI, fines, laminated (lacustrine); Fr, fines, plant remains; Ft, fines, thin-bedded. C) Texture (dominant granulometry), brief observations and AMS dating laboratory code. D) Bedding and stacking (ig $=$ inversed graded, gr $=$ graded). Parasequence upward stacking (Fining/Coarsening, Thinning/Thickening). F) Alluvial facies association. G) Magnetic susceptibility diagram. The mean value dotted line plotted in vertical. Explanation of the labelled values in text. H) Dynamic cone penetration resistance diagram from the DPSH probe. I) Major sequence boundary (SB), Unconformity Surfaces (US), Condensed Sections (CS) produced in Forced High Stand. Maximum flooding Surface (mfs). J) Charcoals and charred materials in $\mathrm{mm}^{2} / \mathrm{kg}$; "A" Alleröd interstadial. K) LOI content; "OD" Older Dryas; "IACP" Intra Cold Alleröd Period; "YD" Younger Dryas. L) Fine grain cored samples. 
1217 Fig. 4. Discontinuous function for the Navamuño age model. 1) Logarithmic trend 1218 provides an age close to $27 \mathrm{Ka} \mathrm{Cal} \mathrm{BP}$ for the starting point of the lacustrine 1219 sedimentation by ice-damming. 2) Polynomial trend between $\sim 6$ and $15 \mathrm{~m}$ depth. 3) 1220 Polynomial trend taking into account inversion at $15 \mathrm{~m}$ depth.

Fig. 5. A) Cuerpo de Hombre paleoglacier during the maximum ice extent (MIE) and 1223 position of the available cosmogenic ages, arrows showing the flow ice directions. B) 1224 Longitudinal profile across the Navamuño neighbouring Cuerpo de Hombre glaciated 1225 valley (I-II, see Fig. A), showing the chronology and position of the different advance and recession phases from the Cuerpo de Hombre paleoglacier. C) Former accumulation zone of Cuerpo de Hombre glacier. D) Panoramic view of Cuerpo de Hombre valley showing basement scarp limiting sharply the glacier tongue extension in the Oldest Dryas. The data used in this figure are based on Carrasco et al. (2015a). 

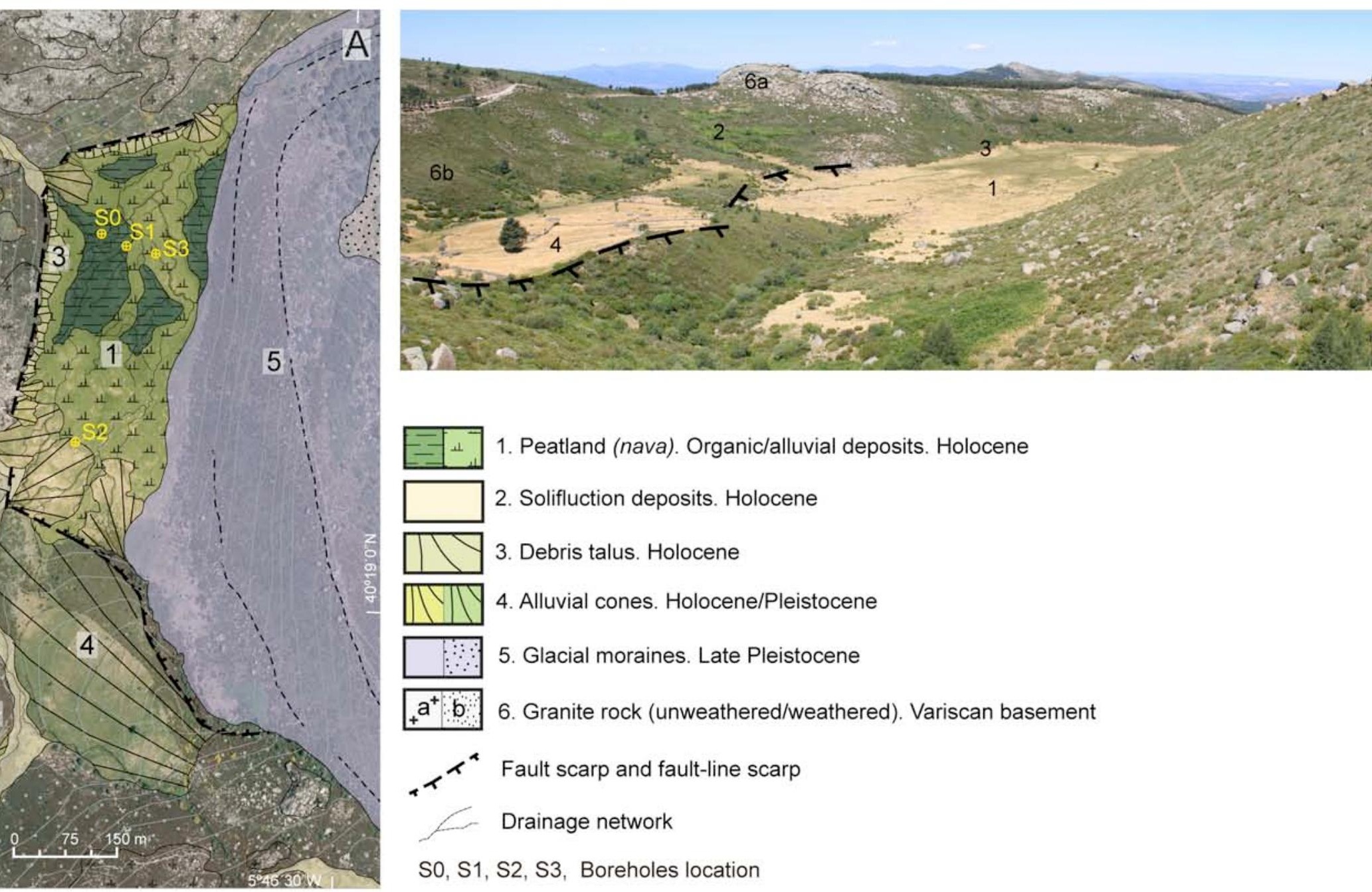

1. Peatland (nava). Organic/alluvial deposits. Holocene

2. Solifluction deposits. Holocene

3. Debris talus. Holocene

IIV 4. Alluvial cones. Holocene/Pleistocene

$\therefore$ 5. Glacial moraines. Late Pleistocene

${ }_{+} a^{+}$6. Granite rock (unweathered/weathered). Variscan basement

$\boldsymbol{x}^{4}$ Fault scarp and fault-line scarp

$\sum$ Drainage network

S0, S1, S2, S3, Boreholes location 


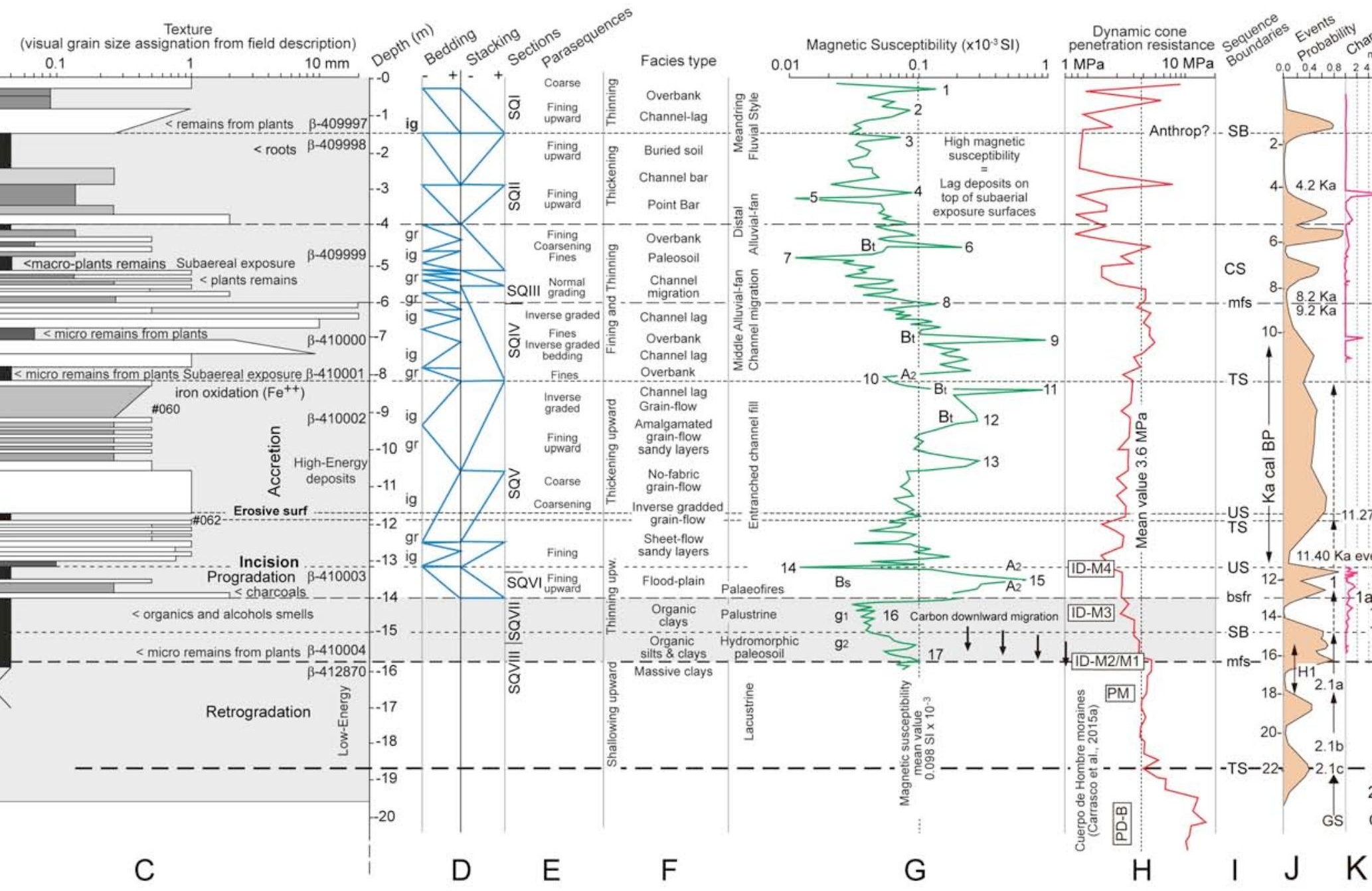




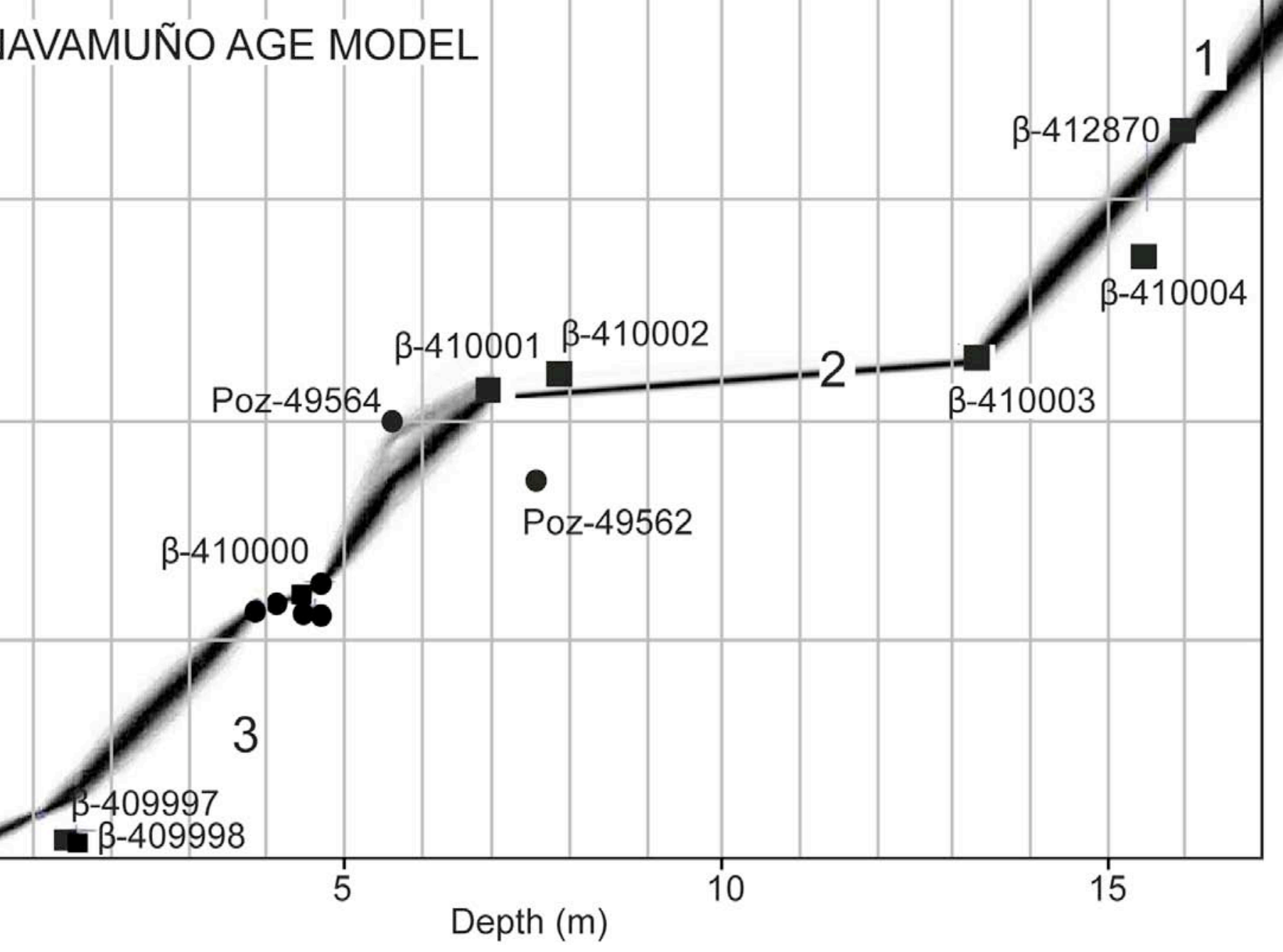



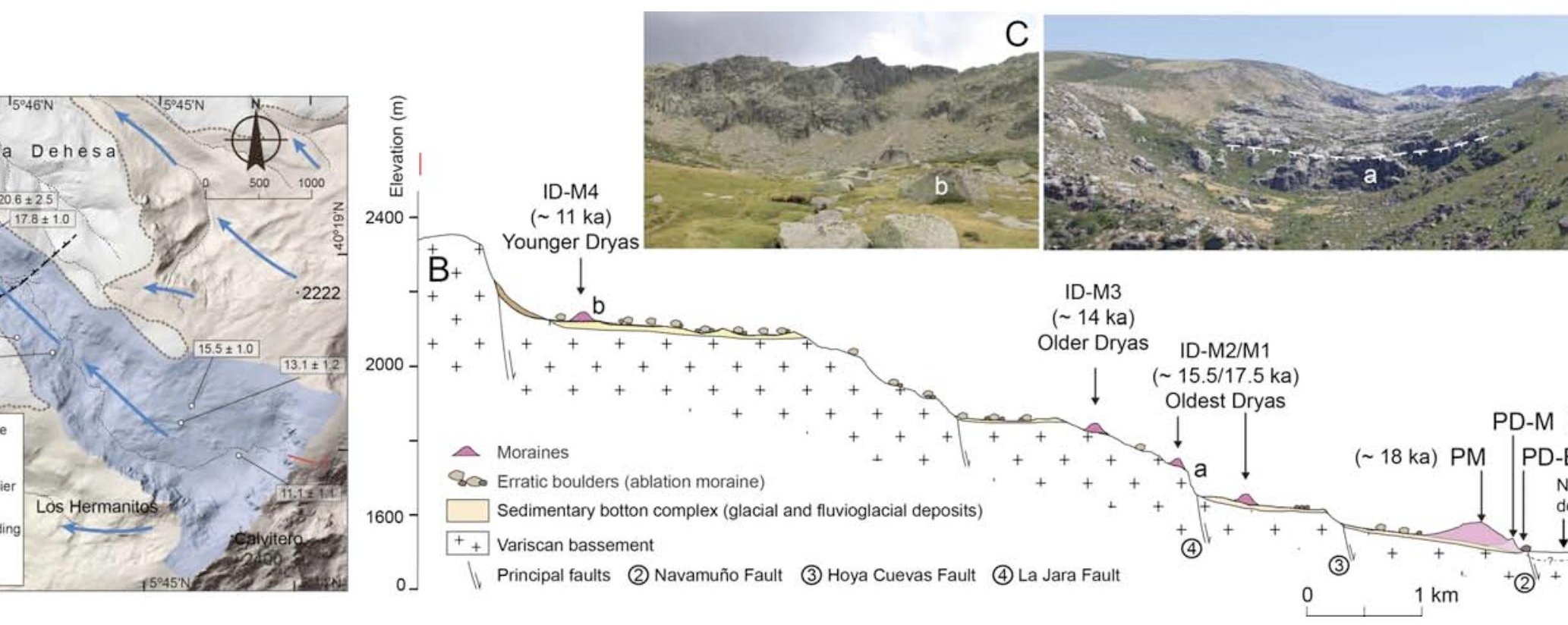
Table 1. Boreholes performed in the Navamuño depression.

\begin{tabular}{cccccc}
\hline Borehole & $\begin{array}{c}\text { Latitude } \\
\text { (DD) }\end{array}$ & $\begin{array}{c}\text { Longitude } \\
(\mathrm{DD})\end{array}$ & $\begin{array}{c}\text { Elevation } \\
(\mathrm{m} \text { asl })\end{array}$ & $\begin{array}{c}\text { Engine } \\
\text { used }\end{array}$ & $\begin{array}{c}\text { Depth } \\
(\mathrm{m})\end{array}$ \\
\hline S0 & 40.321426 & -5.779319 & 1503 & HPEA & 4.75 \\
S1 & 40.321286 & -5.778895 & 1504 & MED & 8 \\
S2 & 40.318700 & -5.779672 & 1506 & MED & 5 \\
S3 & 40.321196 & -5.778397 & 1505 & DP & 16 \\
\hline
\end{tabular}

$\mathrm{DD}$, decimal degrees; $m$ asl, metres above sea level; HPEA, handheld power earth auger; MED, mechanized earth driller; DP, direct push 
Table 2. Results of radiocarbon analysis. IntCal13 radiocarbon age calibration from Reimer et al. (2013).

\begin{tabular}{cccccccccc}
\hline Sample & Dated depth & Auger & Year & Material & BP & $2 \sigma$ & $\delta^{13} \mathrm{C}(\%)$ & $\mathrm{P}(\mathrm{x}) \%$ & Cal BP age \\
\hline Poz-40321 & $4.20-4.26 \mathrm{~m}$ & $\mathrm{~S} 0$ & 2011 & Vegetal & 5070 & 35 & n.a & 100 & $5739-5908$ \\
Poz-40322 & $4.45-4.50 \mathrm{~m}$ & $\mathrm{~S} 0$ & 2011 & Vegetal & 5160 & 40 & n.a & 83.97 & $5881-5994$ \\
Poz-40324 & $4.69-4.75 \mathrm{~m}$ & $\mathrm{~S} 0$ & 2011 & Vegetal & 4940 & 35 & n.a & 100 & $5601-5733$ \\
Poz-40509 & $4.69-4.75 \mathrm{~m}$ & $\mathrm{~S} 0$ & 2011 & Vegetal & 4790 & 40 & n.a & 96.6 & $5464-5601$ \\
Poz-50407 & $3.94 \mathrm{~m}$ & $\mathrm{~S} 1$ & 2012 & Betula sp & 5010 & 35 & n.a & 61.8 & $5654-5772$ \\
Poz-50408 & $4.52 \mathrm{~m}$ & $\mathrm{~S} 1$ & 2012 & Betula sp & 4950 & 60 & n.a & 86.2 & $5588-5764$ \\
Poz-50410 & $4.85 \mathrm{~m}$ & $\mathrm{~S} 1$ & 2012 & Betula sp & 4990 & 35 & n.a & 18.4 & $5819-5887$ \\
Poz-49562 & $5.65-5.70 \mathrm{~m}$ & $\mathrm{~S} 1$ & 2012 & Bulk & 8950 & 50 & n.a & 56.9 & $9914-10099$ \\
Poz-49564 & $7.55-7.60 \mathrm{~m}$ & $\mathrm{~S} 1$ & 2012 & Bulk & 7890 & 40 & n.a & 83.3 & $8590-8793$ \\
Poz-49561 & $3.75-3.78 \mathrm{~m}$ & $\mathrm{~S} 2$ & 2012 & Bulk & 7530 & 40 & n.a & 90.9 & $8298-8411$ \\
$\beta-409997$ & $1.11 \mathrm{~m}$ & $\mathrm{~S} 3$ & 2015 & Bulk & 990 & 30 & -25.7 & 39.7 & $798-870$ \\
$\beta-409998$ & $1.59 \mathrm{~m}$ & $\mathrm{~S} 3$ & 2015 & Vegetal & 450 & 30 & -26.8 & 100 & $472-535$ \\
$\beta-409999$ & $4.75 \mathrm{~m}$ & $\mathrm{~S} 3$ & 2015 & Vegetal & 5500 & 30 & -26.8 & 79.7 & $6272-6324$ \\
$\beta-410000$ & $7.00 \mathrm{~m}$ & $\mathrm{~S} 3$ & 2015 & Vegetal & 9450 & 30 & -25.9 & 79.6 & $10636-10754$ \\
$\beta-410001$ & $7.85 \mathrm{~m}$ & $\mathrm{~S} 3$ & 2015 & Vegetal & 9530 & 30 & -27.9 & 48.46 & $10949-11072$ \\
$\beta-410002$ & $9.10 \mathrm{~m}$ & $\mathrm{~S} 3$ & 2015 & Vegetal & $103.9 \pm 0.3$ & pMC & -27.3 & n.a & $104.5 \pm 0.3 \mathrm{pMC}$ \\
$\beta-410003$ & $13.3 \mathrm{~m}$ & $\mathrm{~S} 3$ & 2015 & Bulk & 9980 & 40 & -26.9 & 100 & $11264-11619$ \\
$\beta-410004$ & $15.5 \mathrm{~m}$ & $\mathrm{~S} 3$ & 2015 & Vegetal & 11920 & 40 & -29.3 & 98.5 & $13568-13835$ \\
$\beta-412870$ & $16.0 \mathrm{~m}$ & $\mathrm{~S} 3$ & 2015 & Bulk & 13720 & 40 & -25.5 & 100 & $16339-16800$ \\
\hline
\end{tabular}




\section{Quaternary International}

We the authors declare that this manuscript is original, has not been published before and is not currently being considered for publication elsewhere.

We confirm that the manuscript has been read and approved by all named authors and that there are no other persons who satisfied the criteria for authorship but are not listed. We further confirm that the order of authors listed in the manuscript has been approved by all of us.

We understand that the Corresponding Author is the sole contact for the Editorial process.

$\mathrm{He} / \mathrm{She}$ is responsible for communicating with the other authors about progress, submissions of revisions and final approval of proofs.

Sincerely,

On behalf of all authors

25 February 2017

Valentí Turu 